\title{
Molecular mechanisms of gonadotropin-releasing hormone signaling: integrating cyclic nucleotides into the network
}

\author{
Rebecca M. Perrett and Craig A. McArdle* \\ Laboratories for Integrative Neuroscience and Endocrinology, School of Clinical Sciences, University of Bristol, Bristol, UK
}

\section{Edited by:}

Rob Charles Fowkes, Royal Veterinary

College, UK

\section{Reviewed by:}

P. Michael Conn, Oregon Health and Science University; Oregon National

Primate Research Center, USA

Andrew Wolfe, Johns Hopkins

University, USA

Ryan Miller, Johns Hopkins

University, USA

*Correspondence:

Craig A. McArdle, Laboratories for Integrative Neuroscience and

Endocrinology, School of Clinical

Sciences, University of Bristol, 1

Whitson Street, Bristol BS1 3NY, UK

e-mail: craig.mcardle@bristol.ac.uk
Gonadotropin-releasing hormone $(\mathrm{GnRH})$ is the primary regulator of mammalian reproductive function in both males and females. It acts via G-protein coupled receptors on gonadotropes to stimulate synthesis and secretion of the gonadotropin hormones luteinizing hormone and follicle-stimulating hormone. These receptors couple primarily via Gproteins of the $G_{q / l l}$ family, driving activation of phospholipases $C$ and mediating $\mathrm{GnRH}$ effects on gonadotropin synthesis and secretion. There is also good evidence that $\mathrm{GnRH}$ causes activation of other heterotrimeric $G$-proteins $\left(G_{s}\right.$ and $\left.G_{j}\right)$ with consequent effects on cyclic AMP production, as well as for effects on the soluble and particulate guanylyl cyclases that generate cGMP. Here we provide an overview of these pathways. We emphasize mechanisms underpinning pulsatile hormone signaling and the possible interplay of $\mathrm{GnRH}$ and autocrine or paracrine regulatory mechanisms in control of cyclic nucleotide signaling.

Keywords: GnRH, G-proteins, phospholipase C, adenylyl cyclase, guanylyl cyclase, ERK, PACAP, natriuretic peptide

\section{GONADOTROPIN-RELEASING HORMONE RECEPTORS AND EFFECTORS}

Gonadotropin-releasing hormone (GnRH) (pGlu-His-Trp-SerTyr-Gly-Leu-Arg-Pro-Gly- $\mathrm{NH}_{2}$ ), also known as luteinizing hormone-releasing hormone (LHRH) or GnRH I, is a hypothalamic neuropeptide that mediates central control of reproduction in both males and females. It is synthesized in hypothalamic neurons and secreted from the hypothalamus into the hypophyseal portal circulation in pulses which are most often of a few minutes duration. It acts via GnRH receptors (GnRHRs) on gonadotropes within the anterior pituitary, stimulating the synthesis and secretion of luteinizing hormone ( $\mathrm{LH})$ and follicle-stimulating hormone (FSH), thereby controlling gametogenesis and steroidogenesis (1-6). GnRH is absolutely required for reproduction as demonstrated by mutation of the genes encoding GnRH or its receptor (7-9).

Molecular phylogeny of GnRH ligands shows that there are three distinct forms, GnRH-I, GnRH-II, and GnRH-III that arose from a common origin which predates vertebrates (10). Most vertebrate classes have GnRH-I and GnRH-II $(1,3,11)$, whereas

\footnotetext{
Abbreviations: $\mathrm{Ca}^{2+}$, calcium; cAMP, cyclic adenosine $3^{\prime}, 5^{\prime}$-monophosphate; EFP emerald fluorescent protein; EGF, epidermal growth factor; ERK, extracellular signal-regulated kinase, here used to denote ERK1 and ERK2; FAK, focal adhesion kinase; FSH, follicle-stimulating hormone; GFP, green fluorescent protein; $\mathrm{GnRH}$, gonadotropin-releasing hormone also known as GnRH I; GnRHR II, gonadotropinreleasing hormone II, also known as chicken GnRH; GnRHR, GnRH receptor; GPCR, G-protein coupled receptor; GRK, G-protein coupled receptor kinase; IP, inositol phosphate; JNK, c-Jun N-terminal kinase; LH, luteinizing hormone; MAPK, mitogen-activated protein kinase; MEK, MAPK/ERK kinase; NFAT, nuclear factor of activated T-cells; NO, nitric oxide; PKC, protein kinase C; PLC, phospholipase C.
}

GnRH-III has only been found in teleosts (12-23). Interestingly, the GnRH-I sequence has diverged in the vertebrate lineage, whereas the sequences of GnRH-II and GnRH-III are completely conserved across vertebrates $(3,10,24)$.

\section{CLINICAL USES}

Gonadotropin-releasing hormone analogs are used clinically, either to mimic its stimulatory effects, such as the treatment of infertility with pulsatile administration of a natural sequence of GnRH to induce ovulation or spermatogenesis $(3,25)$, or to block its effects. The latter can be achieved either using GnRH antagonists $(1-6,26,27)$, or, paradoxically, with sustained exposure to GnRH (or metabolically stable GnRH agonists), which causes stimulation followed by desensitization of GnRHRmediated gonadotropin secretion $(3,25)$. In both cases blockade or desensitization of GnRHR-mediated gonadotropin secretion ultimately reduce circulating levels of gonadotropins and gonadal steroids, and in this fashion GnRH analogs can be used to treat sex hormone-dependent neoplasms such as those of the prostate, ovary, endometrium, or mammary glands $(1-6,28)$.

\section{GONADOTROPIN-RELEASING HORMONE}

GnRH receptors belong to the rhodopsin-like G-protein coupled receptor (GPCR) family, and are thus characterized by a seven trans-membrane $\alpha$ helical domain structure (3, 29, 30). GnRHRs can be classified into three groups based on sequence homology. All of the cloned mammalian GnRHRs are in groups I or II (3, 24 ) and the type I GnRHRs of humans, rats, mice, pigs, sheep, and horses have $>80 \%$ amino acid sequence homology (31). Except in certain primate species, notably the marmoset, rhesus, and green 
monkey, the type I receptor is the functional and predominant form expressed in the mammalian gonadotrope, and in some species it is also expressed in extra-pituitary tissues including breast, gonads, prostate, and uterus $(32,33)$. This extra-pituitary expression is also evident in numerous cancers, including breast, prostate and ovary, and on in vitro or in vivo tumor models $\mathrm{GnRH}$ analogs or cytotoxic derivatives show promise as anti-proliferative and/or pro-apoptotic agents (34-40).

In common with many other GPCRs, GnRHRs of gonadotropes and gonadotrope-lineage cells act primarily via $\mathrm{G} \alpha_{\mathrm{q} / 11}$ to activate phospholipase C (PLC), thus elevating cytoplasmic $\left[\mathrm{Ca}^{2+}\right]$ and activating protein kinase $\mathrm{C}(\mathrm{PKC})$ isozymes, both of which are important for GnRHR-mediated effects on gonadotropin synthesis and secretion (Figure 1) (2-6, 29, 31, 41-46). The mammalian type I GnRHR is a structurally and functionally unique member of the GPCR family in that it lacks an intracellular cytoplasmic C-terminal tail $(3,47,48)$. For many GPCRs, the C-tail plays a key role in desensitization and trafficking $(49,50)$. The C-terminal tail of typical GPCRs is phosphorylated on Ser and Thr residues following activation, generating a docking site for non-visual arrestins (arrestins 2 and 3) that prevent G-protein activation, a process termed homologous receptor desensitization. The phosphorylated tails also act as adapters targeting the desensitized receptors for internalization, a process that can lead to receptor down-regulation, or recycling and resensitization $(49,51)$. The absence of a C-terminal tail would therefore imply an inability of the type I mammalian GnRHR to undergo agonist-induced phosphorylation or bind arrestins, with relatively slow internalization and resistance to rapid desensitization, all of which have been confirmed experimentally (51-61). In addition, fusing the C-terminal of various GPCRs to the type I mammalian GnRHR causes rapid desensitization and internalization $(51,54,62-65)$. Both the rat and human GnRHR internalize in a clathrin-dependent manner, and colocalize with transferrin, which is internalized via clathrin-coated structures $(54,56,59)$. The rat GnRHR internalizes in a dynamin dependent manner (64), whereas the human internalizes independently of dynamin (47). Contrastingly, upon activation type II GnRHRs do undergo rapid agonist-induced
A

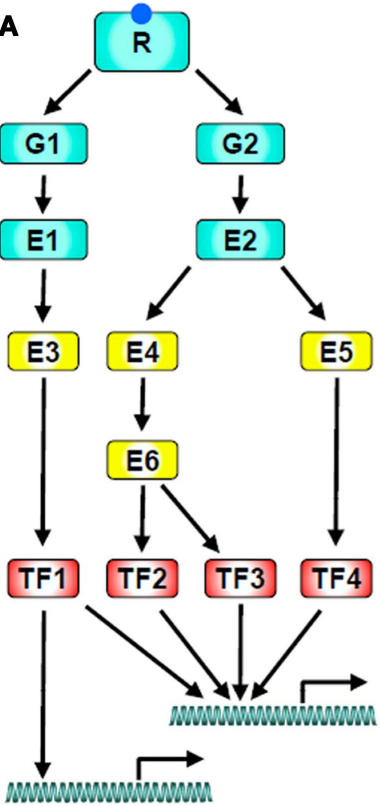

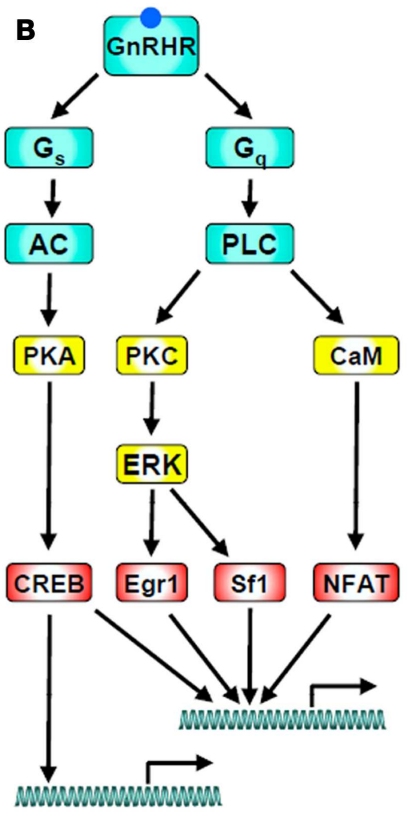

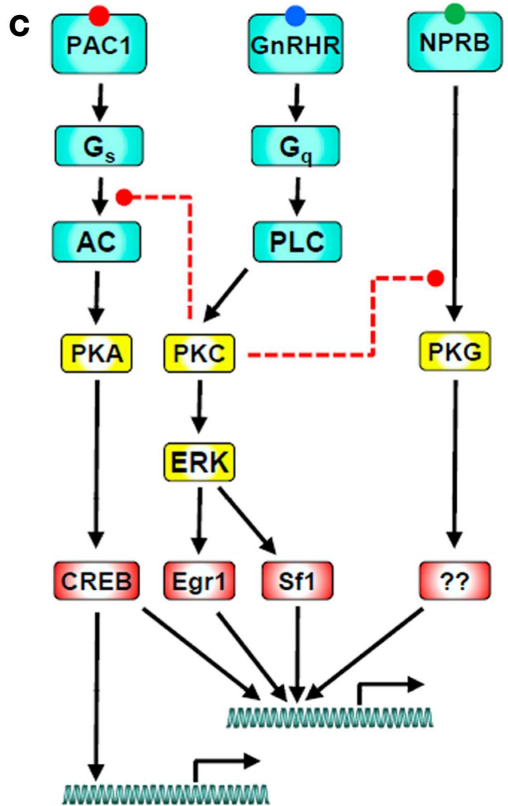

FIGURE 1 | GnRH receptor signaling networks. (A) Illustrates a generic signaling network in which a GPCR activates two heterotrimeric G-proteins (G1 and G2) which activate their cognate effectors (E1 and E2). These directly or indirectly activate down-stream effectors that influence a range of target proteins including transcription factors (TF1-4). The transcription factors then act (typically in combination) to influence expression of numerous target genes. Note that the network has multiple sites for divergence and convergence. (B) Shows a GnRH signaling network with the same architecture; The GnRHR activates Gs and Gq leading to activation of adenylyl cyclase (AC) and phospholipase $C$ (PLC). AC generates CAMP, stimulating PKA which activates the transcription factor CREB. PLC leads to activation of PKC, driving activation of ERK and of ERK-dependent transcription via Sf-1 and Egr-1. It also elevates the cytoplasmic $\mathrm{Ca}^{2+}$ concentration, driving activation of calmodulin and its targets, including calcineurin which leads to activation of the $\mathrm{Ca}^{2+}$-dependent transcription factor NFAT. This cartoon is clearly a vast oversimplification as important effectors (including calmodulin-dependent kinases, JNK, p38, and nitric oxide synthase) are not included. Perhaps more importantly, it also excludes signal dynamics and heterologous regulation, both of which are important for control of gonadotropes. A simple example of the latter is given in $\mathbf{( C )}$ which includes the PAC1 receptor as a mediator of PACAP-stimulated AC activation, and the NPRB receptor as a mediator of CNP-stimulated cGMP accumulation and consequent protein kinase G (PKG) activation. $\mathrm{GnRH}$ can cause PKC-mediated inhibition of PACAP-stimulated cAMP accumulation and of CNP-stimulated cGMP accumulation (as indicated by the dashed red lines), raising the possibility that its predominant effect is actually inhibition of these pathways in gonadotropes exposed to autocrine or paracrine stimulation of PAC1 and NPRB. Finally, when considering signal dynamics, it is important to recognize: (a) that $\mathrm{GnRH}$ is secreted in pulses, (b) that the responses illustrated have distinct kinetics, (c) that the kinetics of convergent pathways are important determinants of $\mathrm{GnRH}$ pulse frequency-response relationships, and (d) that $\mathrm{GnRH}$ influences the expression of many genes encoding components of the GnRHR signaling pathways, with transcription-dependent feedback loops supporting an adaptive signaling network. 
phosphorylation, recruit arrestins, and internalize via clathrincoated pits (47). The requirement for arrestins and dynamin is species specific $(3,66,67)$, but the presence of the C-terminal tail is crucial for rapid agonist-induced internalization (60).

Non-mammalian GnRHRs may also activate extracellular signal-regulated kinase (ERK) in an arrestin-mediated manner. Arrestins can act as adaptors for signaling molecules, for example cRafl and the ERK mitogen-activated protein kinase (MAPK), both of which can bind to MAPK/ERK kinase (MEK), and could therefore participate in MAPK activation (68-72). Arrestinmediated ERK signaling appears specific for non-mammalian GnRHRs; in cells either expressing a mouse type I or a Xenopus laevis GnRHR, both caused G-protein-dependent ERK activation but arrestin-mediated ERK activation was only seen with the Ctail expressing Xenopus $\operatorname{GnRHR}(73,74)$. An interesting possibility is that the C-terminal tail was lost through evolution because the GnRH pulses that gonadotropes are exposed to would be too short to evoke desensitization of a C-tailed receptor, such that there was no selective advantage for retention of the structure. Alternatively, its loss may be related to the pre-ovulatory gonadotropin surge that is driven by $\mathrm{GnRH}$ pulses of increasing frequency and possibly also increased amplitude and a failure to return to basal levels between frequent pulses. Receptor desensitization under such conditions could conceivably prevent the pre-ovulatory gonadotropin surge, providing a positive adaptive advantage for loss of the rapid homologous receptor desensitization mechanism.

\section{HETEROTRIMERIC G-PROTEIN COUPLING}

In pituitary gonadotropes, GnRHR signaling is primarily mediated by $\mathrm{G} \alpha_{\mathrm{q} / 11}$ subunits, although $\mathrm{GnRHR}$ coupling to $\mathrm{G} \alpha_{\mathrm{i}}$ and $\mathrm{G} \alpha_{\mathrm{s}}$, as well as $\mathrm{G} \alpha_{\mathrm{q} / 11}$ have also been reported (75-78). Agonist binding is associated with GTP loading of $\mathrm{G} \alpha_{\mathrm{q} / 11}$, which activates phospholipase $\mathrm{C} \beta$ (PLC $\beta$ ), elaborating the second messengers inositol 1,4,5-trisphosphate $\left(\mathrm{IP}_{3}\right)$, and diacylglycerol (DAG). $\mathrm{IP}_{3}$ mediates $\mathrm{Ca}^{2+}$ release from intracellular stores, and DAG causes activation of PKC isozymes (Figure 1). A more sustained rise of intracellular $\mathrm{Ca}^{2+}$ occurs via the opening of L-type voltage gated channels and subsequent $\mathrm{Ca}^{2+}$ influx $(1-6,79)$. Progressively increasing GnRH concentrations cause three different $\mathrm{Ca}^{2+}$ responses, subthresholds, baseline oscillations, and biphasic responses (80-82). The initial spike phase is due to mobilization of $\mathrm{Ca}^{2+}$ from intracellular stores, which is involved in early GnRH-stimulated LH release (83), whereas the plateau corresponds to $\mathrm{Ca}^{2+}$ entry through voltagedependent $\mathrm{Ca}^{2+}$ channels. The oscillatory responses are generated through a cytoplasmic $\mathrm{Ca}^{2+}$ oscillator model (84). Rapid effects of GnRH on exocytotic gonadotropin secretion are mediated by elevation of cytoplasmic $\mathrm{Ca}^{2+}$ and modulated by activation of PKC. These signaling intermediates, and effectors including calmodulin and calmodulin-dependent protein kinases (CaMKs), also mediate chronic effects of GnRH on gene expression.

Gonadotropin-releasing hormone effects on gonadotropin synthesis are largely mediated through stimulation of MAPK cascades, particularly the ERK pathway (Figure 1) (85), which is PKC dependent in $\alpha \mathrm{T} 3-1$ and L $\beta$ T2 gonadotrope-derived cells (79). PKC and ERK mediate the transcriptional effects of $\mathrm{GnRH}$ on the common $\alpha$-gonadotropin subunit ( $\alpha \mathrm{GSU})(86-89)$, as well as LH $\beta$ (90-93) and FSH $\beta$ (93-96) subunits. However, there are conflicting reports that GnRH-mediated LH $\beta$ (88) or $\alpha \mathrm{GSU}$ expression $(97,98)$ are independent of ERK and mediated solely by $\mathrm{Ca}^{2+}$. There are also gender specific difference in mice with pituitary specific knockout of ERK1 and 2; females are infertile due to LH deficiency, and ERKs may play a partial role in FSH $\beta$ transcription in these mice, however male reproductive function was normal (99).

In addition to activation of ERK, GnRH can activate the JNK (c-Jun N-terminal kinase), p38, and ERK5 (also known as Big MAPK; BMK) cascades in different cell models with varying kinetics. GnRH stimulates JNK activity in rat pituitaries, $\alpha \mathrm{T} 3-1$ and L $\beta$ T2 cells $(79,100,101)$. JNK has been reported to be involved in transcription of the $\alpha$ GSU subunit $(102,103)$, and the LH $\beta$ and FSH $\beta$ subunits $(94,101,104,105)$. JNK-mediated LH $\beta$ transcription is independent of PKC in L $\beta$ T2 $(90,105)$ and COS $(106)$ cells, with conflicting reports for PKC involvement in $\alpha \mathrm{T} 3-1$ cells (85, $107)$. GnRH also activates $\mathrm{p} 38$ in rat pituitaries, $\alpha \mathrm{T} 3-1$ and L $\beta \mathrm{T} 2$ cells $(91,94,103,104,108)$. A role for p38 in gonadotropin subunit transcription is controversial, with no effect being reported on LH $\beta, F S H \beta$, and $\alpha$ GSU subunits $(91,103,104)$, although an effect on FSH $\beta$ transcription in L $\beta$ T2 cells was reported by others $(94,108)$. GnRH has also been shown to activate ERK5 and stimulate FSH $\beta$ transcription in L $\beta$ T2 cells (109).

$\mathrm{GnRH}$ receptors can also activate a number of other pathways in pituitary gonadotropes, including the adenylyl cyclase (AC)/cyclic adenosine monophosphate (cAMP)/protein kinase A (PKA) pathway $(79,110,111)$. Borgeat et al. (112) demonstrated that GnRHstimulated cAMP production in the rat pituitary, which was later confirmed by Naor et al. (113). GnRH also stimulates cAMP production in L $\beta$ T2 cells $(77,111,114)$, and several heterologous systems including $\mathrm{HeLa}, \mathrm{GH}_{3}$, and COS-7 cells (115-117). However, this was not replicated in $\alpha \mathrm{T} 3-1$ cells or in later studies using rat pituitaries $(45,118,119)$. The coupling mechanism between the GnRHR and the cAMP pathway has yet to be elucidated. The GnRHR has been reported to couple to $\mathrm{G} \alpha_{\mathrm{s}}$ in rat pituitary cells (76), and activate cAMP production via $\mathrm{G} \alpha_{\mathrm{s}}$ recruitment (77). However, in $\alpha$ T3- 1 cells the GnRHR exclusively coupled to $\mathrm{G} \alpha_{\mathrm{q} / 11}$ (120), and activation of $\mathrm{Ca}^{2+} /$ calmodulin sensitive AC isoforms independent of $\mathrm{G} \alpha_{s}$ was proposed as the mechanism of GnRHRinduced cAMP elevation. In addition, the PKC $\delta$ and $\varepsilon$ isoforms were reported to mediate cAMP elevation by $\mathrm{GnRH}$ via activation of AC5 and 7 in L $\beta$ T2 cells (111). However, a more recent study using a biosensor to monitor cAMP mobilization in living cells has demonstrated that GnRH increases cAMP production in $\alpha \mathrm{T} 3$ 1 cells, and that the GnRHR directly interacts with SET protein, which inhibits receptor coupling to calcium and increases coupling to the cAMP pathway, possibly by interfering with $G \alpha_{\mathrm{q} / 11}$ binding to the GnRHR (121). In L $\beta$ T2 and mouse pituitary cells, GnRH activates AMP-activated protein kinase (AMPK) via multiple pathways involving Egr-1 and JNK, and AMPK inhibition suppresses GnRH-stimulated LH $\beta$ transcription (122).

Gonadotropin promoter subunits contain cAMP response elements (CREs) and this provides a mechanism by which the cAMP/PKA pathway might activate gonadotropin subunit transcription (Figure 1). $\alpha \mathrm{T} 3-1$ cells demonstrate a four- to fivefold increase in phospho-CREB (CRE-binding protein) in response to GnRH (123). cAMP stimulates transcription of the mouse, rat, 
and human $\alpha$ GSU genes $(124,125)$, and a cAMP analog increased $\alpha$ GSU mRNA levels in rat pituitary cells, but not that of LH $\beta$ or FSH $\beta$ (126). However, it appears the MAPK cascade, rather than the cAMP pathway, is responsible for gonadotropin promoter CRE activation $(90,100,107,127,128)$. Here it is important to recognize that CREB can be regulated by MAPKs, CaMKs, and PKC as well as by PKA (129). c-Jun and ATF-2, which are known substrates of JNK, were shown to bind to the CRE domain of the $\alpha$ GSU promoter (130). GnRH phosphorylates ATF-2 via p38 and JNK, and upon phosphorylation ATF-2 binds the CRE element within the c-Jun proximal promoter and interacts with nuclear factor Y. Functional ATF-2 is necessary for both GnRH-mediated induction of c-Jun and FSH $\beta$ (131). In addition, GnRH treatment increases expression of ATF-3, which is recruited along with c-Jun and c-Fos to CREs on the $\alpha$ GSU promoter, and GnRHinduced $\alpha \mathrm{GSU}$ gene expression was completely abolished upon mutation of these CREs (132). MAPK signaling and ATF-3 CRE binding are essential for secretogranin II promoter activation by GnRH (133).

GnRH receptors activate a large number of important signaling pathways, notably, they mediate activation of phospholipases A2 and D as well as PLC (41). GnRH-mediated intracellular $\mathrm{Ca}^{2+}$ mobilization, acting through calmodulin, also activates kinases such as $\mathrm{Ca}^{2+} / \mathrm{CaMKs}$, phosphatases such as calcineurin and transcription factors including nuclear factors of activated T-cells (NFATs) (79, 134). GnRHR-induced elevation of intracellular $\mathrm{Ca}^{2+}$ also activates the nitric oxide synthase (NOS I) cascade (NOS $\mathrm{I} / \mathrm{NO} /$ soluble guanylate cyclase) resulting in a rapid increase of cGMP (135-137). However there is no evidence that cGMP is involved in GnRH-induced gonadotropin synthesis or secretion (135) (see subsequent section). GnRH also activates the Wnt/ $\beta$ catenin signaling pathway as well as diacylglycerol kinase, proline rich tyrosine kinase-2, and inhibition of glycogen synthase kinase $(1,6,41,138-140)$.

In addition to directly activating a number of intracellular signaling pathways, in some models GnRHRs can also cause a PKC-dependent proteolytic release of membrane bound epidermal growth factor (EGF) receptor ligands, thereby activating EGF receptors $(1,41)$, whereas in others GnRHRs induce protein phosphatases that apparently inhibit the trophic effects of EGF (78). Moreover, in HEK293 cells stably expressing the type I GnRHR, GnRH causes cytoskeletal remodeling, which correlates with significant increases in the tyrosine phosphorylation status of a series of cytoskeletal associated proteins, including focal adhesion kinase (FAK), c-Src, and ERKs (139). ERK activation is dependent on formation of a complex with FAK and c-Src at focal adhesion complexes, and induction of the cell remodeling event is mediated by activation of the monomeric G-protein Rac, revealing a novel monomeric G-protein-mediated pathway for GnRHR signaling (139).

\section{PULSATILE GnRH SIGNALING}

Gonadotropin-releasing hormone is released from hypothalamic neurons as pulses causing pulsatile gonadotropin release (141, 142), and these pulses are essential for normal reproduction; constant GnRH suppresses LH and FSH secretion, and this can be restored by pulsatile administration (143). GnRH pulses are typically a few minutes in duration, every $30-120$ min according to the species.

It is well established that the frequency of such pulses is extremely variable. For example, GnRH pulse frequency varies over the menstrual cycle with pulses on average every $6 \mathrm{~h}$ in midto late-luteal phases and every 90 min during follicular and early luteal phases (144). Low or intermediate pulse frequencies (pulses every 30-120 $\mathrm{min}$ ) cause a greater increase in expression of rodent $\mathrm{LH} \beta, \mathrm{FSH} \beta$, and the GnRHR as compared to high frequencies (pulses every 8-30 min) or sustained stimulation (145-151). The expression of $\alpha \mathrm{GSU}$ does not exhibit this bell-shaped frequencyresponse relationship and is maximally stimulated by high pulse frequencies or continuous stimulation $(148,149,152,153)$.

The ability of the gonadotrope to interpret varying pulses of GnRH has been the focus of much research, given that differential responses of $\mathrm{LH}$ and FSH occur with varying $\mathrm{GnRH}$ pulse frequency, both in vivo and in vitro. In ovariectomized rhesus monkeys bearing hypothalamic lesions which reduced circulating $\mathrm{LH}$ and FSH to undetectable levels, hourly pulses of GnRH favored LH secretion over FSH, whereas pulses every $3 \mathrm{~h}$ favored FSH secretion and caused a decline in LH levels (154). Additional in vivo studies with $\mathrm{GnRH}$ deficient men recapitulated this observation $(155,156)$, as do in vitro studies using pituitary cultures (145$151,157)$, with intermediate pulse intervals ( $30 \mathrm{~min}-1 \mathrm{~h}$ ) favoring LH $\beta$ transcription and low frequencies (every $3 \mathrm{~h}$ ) that of FSH $\beta$. Although most work on GnRHR signaling has involved sustained stimulation, similar signaling mechanism appear to be involved in response to pulsatile stimulation, including activation a number of key effectors including $\mathrm{G} \alpha_{\mathrm{q} / 11}, \mathrm{G} \alpha_{\mathrm{s}}$, and $\mathrm{G} \alpha_{\mathrm{i}}(41,79,158)$. Downstream of $\mathrm{G} \alpha_{\mathrm{q} / 11}$, the $\mathrm{Ca}^{2+} /$ calmodulin/calcineurin/NFAT and Raf/MEK/ERK signaling modules are both activated (159, 160) (see below), and gonadotrope ERK has been shown to be essential for reproduction (99) consistent with its role as an effector of pulsatile GnRHR activation in vivo.

The mechanisms by which gonadotropes decode GnRH pulse frequency are largely unknown, despite the fact that this frequencyencoded signal is crucial for the physiology and therapeutic manipulation of the reproductive system $(2,27,99,109,159-162)$. A key feature of this system is that maximal responses to some effects of GnRH occur with sub-maximal pulse frequencies. In essence this means that there is a bell-shaped frequency-response curve for some effects of $\mathrm{GnRH}$, behavior that has been termed "genuine frequency decoding" (163) to distinguish it from the simpler situation where increasing pulse frequencies elicit increasing responses up to the maximal pulse frequency (i.e., constant stimulation). The bell-shaped frequency-response curve is thought to require more complex systems involving feed-forward or feedback regulation (163) and is exemplified by the non-monotonic relationships seen for effects of GnRH on LH $\beta$ or FSH $\beta$ expression (as measured using luciferase reporters). However the nature of the negative feedback loop is unclear. It could lie at the level of upstream components of the GnRHR cascade; GnRH causes down-regulation of cell surface GnRHRs (164) and a recent mathematical model of GnRH signaling predicts desensitization due to down-regulation of cell surface GnRHRs, which is more pronounced at higher pulse frequency (165). It cannot however be due to rapid homologous receptor desensitization as type I mammalian GnRHRs do not 
show this behavior (58). Alternatively, transcription-dependent negative feedback on upstream inputs could occur at high $\mathrm{GnRH}$ pulse frequency. This could include GnRHR-mediated induction of regulator of G-protein signaling (RGS)-2 which displays GTPase activating protein activity and is known to inhibit $\mathrm{G} \alpha_{\mathrm{q} / 11}$ signaling $(166,167)$, direct interaction of the GnRHR with SET protein which may inhibit $\mathrm{G} \alpha_{\mathrm{q} / 11}$ binding (121), or induction of MAPK phosphatases (MKPs) which would modulate GnRHRmediated ERK signaling (109). GnRH also causes down-regulation of $\mathrm{IP}_{3}$ receptors $(168,169)$, and induces expression of calmodulindependent small G-protein Kir/Gem (kinase-inducible Ras-like protein/GTP binding protein over-expressed in skeletal muscle), which is known to inhibit $\mathrm{Ca}^{2+}$ channels (145). Finally, the feedback or feed-forward regulatory loops could lie further downstream, within the nucleus. Low pulse frequency causes transient Egr-1 expression, causing expression of co-repressor Nab-2, thus inhibiting $\mathrm{LH} \beta$ expression. With high GnRH pulse frequencies there is a more sustained increase in Egr-1, which increases LH $\beta$ transcription by quenching Nab-2 (162). However, neither upregulation of Nab-1 and Nab-2, or differential expression of Egr-1, were observed in vivo (101). The proteasome has been proposed to play a role in cyclical hormonal responses, by targeting transcription factors for degradation and thus freeing the promoter to enable it to respond to the next pulse of hormone (170) GnRHmediated LH $\beta$ gene expression is dependent on protein degradation via the proteasome, and Egr-1 and SF-1, two key transcription factors for $\mathrm{LH} \beta$, are targets of the ubiquitin-proteasome system (171). Targeting transcription factors for degradation would promote gonadotrope sensitivity, allowing more rapid transcriptional responses to changes in GnRH concentration.

There appears to be selective interplay of factors at the Fshb promoter according to pulse frequency: mutation of a CRE site within the FSH $\beta$ promoter resulted in loss of preferential GnRH stimulation at low pulse frequencies (161), and low pulse frequencies stimulated PKA activity and levels of phospho-CREB compared to high pulse frequencies (172). AP-1 family members FOS and JUN positively regulate the $F s h b$ promoter and are induced at low GnRH pulse frequencies, whereas SKIL and TGIF1 corepressors negatively regulate the $F$ sh $b$ promoter, and are induced at higher frequencies (173), along with ICER, which antagonizes the stimulatory action of CREB to attenuate FSH $\beta$ transcription (161). As well as inducing c-Fos expression, low GnRH pulse frequencies act via the ERK1/2 pathway to cause c-Fos phosphorylation, which extends its half-life, thereby enhancing FSH $\beta$ transcription (174).

In order to test for upstream feedback mechanisms during pulsatile GnRH signaling, we have used live cell imaging reporters including an NFAT1c-emerald fluorescent protein (NFAT-EFP) and ERK2-GFP $(159,175)$. Nuclear translocation of NFAT-EFP provides a readout for elevation of intracellular $\mathrm{Ca}^{2+}$ because the $\mathrm{Ca}^{2+} /$ calmodulin-dependent activation of calcineurin causes dephosphorylation of cytoplasmic NFAT that exposes a nuclear localization sequence (176). Similarly, activation of ERK causes it to be released from cytoplasmic scaffolds and facilitates proteinprotein interaction necessary for nuclear entry, such that the redistribution of ERK2-GFP from the cytoplasm to the nucleus can provide a readout for activation of the Raf/MEK/ERK cascade. In HeLa cells transduced to express type I GnRHR, pulsatile
GnRH caused rapid NFAT-EFP and ERK2-GFP nuclear translocation, but with markedly different response kinetics. With $5 \mathrm{~min}$ GnRH pulses, ERK2-GFP translocated rapidly to and from the nucleus and the nuclear:cytoplasmic (N:C) ERK2-GFP measure returned to basal values between stimuli, whereas the $\mathrm{N}: \mathrm{C}$ NFAT-EFP response was slower in onset and offset so that at high pulse frequency the response had not returned to the prestimulation value before a subsequent stimulus was added (159, 175). This led to "saw-tooth" or cumulative response, thought to increase signal efficiency with pulsatile stimuli (177). Irrespective of these differences, there was no evidence for desensitization of responses to pulsatile GnRH using these readouts (175) and maximal responses were seen at maximal $\mathrm{GnRH}$ pulse frequency. In contrast, maximal effects were seen with sub-maximal pulse frequencies when luciferase reporters containing $\mathrm{LH} \beta$ or FSH $\beta$ promoters were used as experimental readouts. Thus, the bellshaped frequency-response curve or "genuine frequency decoding" of $\mathrm{GnRH}$ pulses is not a specific feature of gonadotropes and can occur in the absence of the negative feedback previously thought to explain it.

The studies outlined above focused on the $\mathrm{Ca}^{2+} /$ calmodulin/ calcineurin/NFAT and Raf/MEK/ERK pathways because both mediate transcriptional effects of GnRH and both decode pulse frequency in other models (178-183). The promoter regions of gonadotropin genes contain response elements likely to mediate the effects of ERK (i.e., Egr-1 sites) and NFAT (181), and the Raf/MEK/ERK and $\mathrm{Ca}^{2+} /$ calmodulin/calcineurin/NFAT cascades are known to act as co-dependent modules in other systems, notably in the control of cardiac myocyte proliferation where ERK and NFAT converge on composite AP-1/NFAT response elements in a number of genes $(180,182)$. In spite of this, the empirical data provided no explanation for the observed bell-shaped frequencyresponse relationships so a mathematical approach was taken to explore this further.

We have developed a mathematical model for GnRHR signaling based on a series of ordinary differential equations describing GnRHR occupancy and activation and downstream effectors (27). This differs from earlier models $(109,163,165,184-186)$ in that it incorporates $\mathrm{Ca}^{2+} /$ calmodulin/calcineurin/NFAT and Raf/MEK/ERK modules, includes cellular compartmentalization (i.e., nuclear versus cytoplasm) and importantly, lacks upstream negative feedback. This model accurately predicts wet-lab data for activation and nuclear translocation of ERK2-GFP and NFAT-EFP as validated by modeling responses to $\mathrm{GnRH}$ pulses at a range of concentrations and frequencies, and therefore these two could be used as inputs to the transcriptome. Using this model we considered the possibility that two transcription factors (TF1 and TF2) act at distinct sites on a common gene promoter named gonadotropin subunit (GSU), a generic term used because this is likely the case for the $\alpha \mathrm{GSU}, \mathrm{LH} \beta$, and FSH $\beta$ gonadotropin subunit genes, as it is for many other ERK and NFAT target genes (178-183). We tested three distinct logic gates for the nature of the action of TF1 and TF2 at the promoter (27). The first is a cooperative GATE that in biological terms could reflect the action of one TF to mediate the interaction between the other TF and the cells transcriptional machinery, or alternatively, the requirement of physical interaction between the two TFs to orientate distant 
promoter sites and bring them to close proximity for transcription activation. The second is the AND GATE in which both TFs are needed for transcription activation but there is no functional interaction between them, and the third is the OR GATE where either or both TFs can drive transcription but there is again no functional interaction between the two.

This model predicted bell-shaped frequency-response relationships when two TFs act co-operatively. The characteristic feature of maximal response at sub-maximal frequency was never seen with the AND-gate or with the OR-gate, and this behavior was predicted in the absence of negative feedback which is often assumed to underlie it. This modeling also implied that GnRH pulse frequency-response relationship may be plastic, as varying rate constants for transcription factor activation and inactivation, or varying balance of signaling via NFAT and ERK-dependent transcription factors, influenced the pulse frequency predicted to give a maximal response (27).

The importance of the modeling outlined above is that a bell-shaped frequency-response relationship is predicted to be an emergent feature of co-operative and convergent signaling of two signaling pathways. It requires that the pathways have distinct response kinetics and occurs in spite of the fact that individual pathways and pathway components cannot generate this complex relationship (27). It does not, however, establish that the bell-shaped frequency-response relationships seen for transcriptional effects of $\mathrm{GnRH}$ are necessarily mediated by convergence of NFAT and ERK-dependent transcription factors. In reality, multiple pathways converge to mediate $\mathrm{GnRH}$ effects on transcription, with the relative importance and integration of these inputs being specific for the promoter/enhancer studies (187). In this context, it is of interest that a recent study explored the contribution of $\mathrm{G} \alpha_{\mathrm{s}}$ and $\mathrm{G} \alpha_{\mathrm{q}}$ signaling for pulsatile $\mathrm{GnRH}$ signaling. In this work FRET reporters were used as live cell readouts for activation of the PKA and PLC signaling pathways via the endogenous mouse GnRHR of L $\beta$ T2 cells (188). This revealed that pulses of $\mathrm{GnRH}$ cause pulses of cAMP elevation and PKA activation that are rapid and transient, and do not show measurable desensitization from pulse to pulse (188). This is in accord with the lack of upstream adaptive mechanisms seen with live cell imaging of ERK2-GFP and NFAT-EFP (above). However, the FRET readouts for elevation of $\mathrm{Ca}^{2+}$ and DAG (measures for PLC activation) desensitized rapidly from one pulse to the next (188). This raises the intriguing possibility that co-operative convergent effects of the $\mathrm{G} \alpha_{\mathrm{s}}$ and $\mathrm{G} \alpha_{\mathrm{q}}$ pathways could mediate GnRH pulse frequency decoding and also that the balance of PKA to PLC signaling varies through a series of GnRH pulses. However, the PLC data are puzzling as desensitization of PLC responses with repeated pulses would be expected to be coupled with desensitization of downstream responses, yet repeat pulses of $\mathrm{GnRH}$ can elicit comparable effects on cytoplasmic $\mathrm{Ca}^{2+}$ $(189,190)$, on gonadotropin secretion $(5,191)$, and on NFATEFP translocation (above). It is also unclear why GnRH-mediated PLC activation would desensitize with repeat GnRH pulses, when PLC-mediated $\left[{ }^{3} \mathrm{H}\right] \mathrm{IP}$ accumulation does not show desensitization with up to $60 \mathrm{~min}$ of sustained stimulation $(47,53,57,192)$. Using siRNA and bacterial toxins to specifically perturb individual $\mathrm{G}$ proteins in L $\beta$ T2 cells, Choi et al. demonstrated that FSH $\beta$ expression was dependent on $\mathrm{G} \alpha_{\mathrm{q}}$, whereas $\mathrm{G} \alpha_{\mathrm{s}}$-mediated $\mathrm{LH} \beta$ transcription and suppressed that of FSH $\beta$ (193). Inhibin $\alpha$ was identified as a $\mathrm{G} \alpha_{s}$ dependent $\mathrm{GnRH}$-induced autocrine/paracrine factor which suppresses $\mathrm{FSH} \beta$ transcription. Its transcriptional profile contrasts with that of $\mathrm{FSH} \beta$, being induced by high pulse frequencies, and therefore its absence at low pulse frequencies may explain the preference for FSH $\beta$ transcription.

\section{AUTOCRINE AND PARACRINE REGULATION OF GONADOTROPES}

Given the crucial role of $\mathrm{GnRH}$ in reproduction, it is not surprising that most work on gonadotrope cell signaling has focused on its mode of action. However, gonadotropes are receptive to various other extracellular stimuli, including the gonadal steroids estrogen, progesterone, and testosterone, which as well as acting centrally to influence GnRH secretion, also act directly on the pituitary to modulate $\mathrm{GnRH}$ effects on gonadotropes. In addition to GnRH, gonadotropes are targets for a large number of GPCRactivating ligands (194). These include oxytocin, endothelin-1, galanin, $\beta$-endorphin, neuropeptide $Y$, nucleotides, and pituitary adenylyl cyclase activating polypeptide (PACAP), a highly conserved member of the vasoactive peptide (VIP)-secretin-glucagon peptide superfamily.

Here we highlight some additional signaling pathways key to cyclic nucleotide signaling in the gonadotrope.

\section{PITUITARY ADENYLYL CYCLASE ACTIVATING POLYPEPTIDE}

Pituitary adenylyl cyclase activating polypeptide was originally isolated from sheep hypothalamic extracts based on its ability to stimulate cAMP production by rat pituitary cell cultures (195). It is widely distributed in the nervous, immune, gastrointestinal, cardiac, and endocrine systems $(195,196)$. Two isoforms have been identified, a 38 amino acid form (PACAP38) and C-terminally truncated 27 amino acid form (PACAP27), with PACAP38 accounting for $90 \%$ of the protein in most tissues (194198). The PACAP peptides have $68 \%$ amino acid homology with VIP but are 1000 times more potent in their ability to stimulate cAMP (196).

Three receptors are activated by PACAP; $\mathrm{VPAC}_{1}$, and $\mathrm{VPAC}_{2}$ which have similar affinity for VIP and PACAP, and PAC , which $_{1}$ is highly selective for PACAP (197-200). $\mathrm{PAC}_{1}$ receptors have the potential to couple directly to both $\mathrm{G} \alpha_{\mathrm{s}}$ and $\mathrm{G} \alpha_{\mathrm{q} / 11}$ and exist as multiple splice variants due to alternative splicing of two exons in the third intracellular loop (hip and hop) and are named null (neither hip nor hop), hip, hop1, hop2, hiphop1, and hiphop2 (194, 198, 200-202). Early work showed that (for most PAC 1 variants) PACAP38 and PACAP27 had comparable potency for stimulation of cAMP production, whereas PACAP38 was much more potent than PACAP27 for stimulation of IP accumulation (203).

Within the anterior pituitary, the major secretory cells and folliculo-stellate cells all express at least one type of PACAP receptor $(200,204)$. Various $\mathrm{PAC}_{1}$ receptor forms predominate in the rat pituitary and gonadotrope cell lines (205), and in these cells PACAP activates $\mathrm{PAC}_{1}$, causing a $\mathrm{G} \alpha_{\mathrm{s}}$-mediated stimulation of cAMP production and a $\mathrm{G} \alpha_{\mathrm{q} / 11}$-mediated increase in $\left[\mathrm{Ca}^{2+}\right]_{\mathrm{i}}(194$, 197, 200, 206-211). PACAP regulates gonadotropin secretion and expression of signature genes in gonadotropes either acting alone, or by modulating GnRH effects (194, 197, 200, 210, 212-218). 
PACAP can act alone or synergistically with $\mathrm{GnRH}$ to stimulate LH and FSH production $(216,219)$, although the effect of PACAP on $\mathrm{LH}$ secretion is modest compared to that of GnRH (215). Low pulse frequencies of $\mathrm{GnRH}$ promote PACAP and $\mathrm{PAC}_{1} \mathrm{R}$ expression compared to high pulse frequencies (220). In L $\beta$ T2 cells, high frequencies of PACAP pulses increase LH $\beta$ transcription, whereas low frequencies promote that of FSH $\beta$ (as seen with GnRH pulses) (221). In addition PACAP and $\mathrm{PAC}_{1} \mathrm{R}$ expression increase with lower frequencies of PACAP pulses $(221,222)$. The action of $\mathrm{GnRH}$ in the regulation of gonadotropin subunit expression is enhanced by the presence of $\mathrm{PAC}_{1} \mathrm{Rs}$ (223). At present the mechanisms by which PACAP and its receptor contribute to FSH $\beta$ and $\mathrm{LH} \beta$ expression are unknown, it may act to increase GnRHR expression via a cAMP mediated pathway (224).

Pituitary adenylyl cyclase activating polypeptide increases follistatin expression by gonadotropes and folliculo-stellate cells (211, $225,226)$, and therefore may modulate activin signaling in the pituitary (197). $\mathrm{PAC}_{1}$ receptor activation causes much greater elevation of cAMP than GnRH does in gonadotrope-derived cell lines (200, 208, 209), and GnRH actually causes a PKC-mediated inhibition of PAC $_{1}$-mediated cAMP elevation $(208,227)$. Therefore, if gonadotropes are exposed to stimulatory concentrations of (local or hormonal) PACAP in vivo, GnRH pulses could actually inhibit rather than stimulate CAMP production (208).

\section{NATRUIRETIC PEPTIDES, NITRIC OXIDE, AND GUANYLYL CYCLASES}

The natriuretic peptides atrial-, B-type, and C-type natriuretic peptides (ANP, BNP, and CNP respectively) act via cell surface guanylyl cyclase containing receptors to stimulate cGMP accumulation, which causes activation of protein kinase $G$ (PKG) and cyclic nucleotide gated ion channels (Figure 1) (199). These are single trans-membrane enzymes which are thought to act as homodimers $(199,228)$. There are three subtypes of receptor, NPRA (GC-A) which has high affinity for ANP and BNP, NPRB (GC-B), which is selective for CNP, and the NPRC (GC-C) receptor which binds all three peptides and acts predominantly as a clearance receptor (229). The effects of ANP and BNP on hemodynamic and cardiovascular regulation are well documented (229, 230). The physiological roles of CNP are less clear, although a critical role in endochondral ossification is evident (231). CNP is expressed in LH positive cells of the anterior pituitary $(232,233)$, and female mice with either the CNP (Nppc) or GC-B (Nprb) genes deleted are infertile $(231,234)$.

CNP stimulates cGMP accumulation in GnRH neurons (235), pituitary gonadotropes (236), and endocrine cells of the testis, ovaries, placenta, and uterus (237-244), implying widespread roles of CNP in the hypothalamo-pituitary-gonadal (HPG) axis. In gonadotrope-derived cell lines, CNP activates the $\alpha \mathrm{GSU}$ promoter (233), however it has no effect on LH secretion or GnRHstimulated LH secretion $(228,233,245)$. GnRH causes rapid PKC-mediated inhibition of CNP-stimulated cGMP accumulation in $\alpha$ T3-1 cells $(228,236)$, and may stimulate CNP expression, by transcriptional regulation of the Nppc gene (233). However, little is known about the actions of cGMP in the pituitary, so the physiological relevance of pituitary CNP/NPRA signaling remains unknown.
Gonadotropes also express the enzyme responsible for the generation of nitric oxide (NO), NO synthase (NOS) (246). The NOS enzyme family is composed of three major isoforms, neuronal NOS (nNOS), inducible NOS (iNOS), and endothelial NOS (eNOS). These enzymes convert L-arginine to L-citrulline, producing NO, an important signaling molecule involved in a variety of physiological and pathological processes (247). It exerts physiological effects by activation of soluble guanylyl cyclases to generate cGMP (248). nNOS and eNOS are expressed constitutively and activated by $\mathrm{Ca}^{2+} /$ calmodulin, whereas iNOS is $\mathrm{Ca}^{2+}$. independent $(129,194)$. In the anterior pituitary, nNOS has been specifically detected in the folliculo-stellate cells and gonadotropes $(137,249)$. GnRH stimulates the activity and expression of nNOS in gonadotropes $(136,137,250)$ and this likely explains the increase in nNOS expression and activity observed at proestrous (136). $\mathrm{GnRH}$ may activate the nNOS promoter via cAMP-dependent activation of a CRE in the GnRH-responsive region of the nNOS promoter $(251,252)$. Alternatively it may act via SF-1, which acts on a nuclear hormone receptor binding site on the $\mathrm{nNOS}$ promoter in pituitary gonadotropes to stimulate transcription (253).

Nitric oxide itself inhibits GnRH-stimulated LH secretion, with the NOS inhibitor MeArg markedly potentiating GnRH-induced LH secretion, and the NO donor SNP significantly reducing it $(246,254,255)$. GnRH, LH, and FSH release are decreased in chronic NO deficiency $(256,257)$, and in humans treatment with an NOS inhibitor can reduce GnRH-stimulated $\mathrm{LH}$ and FSH release (258). The effects of NO on gonadotropin secretion remain rather controversial [see Ref. (194) for discussion of stimulatory and inhibitory effects]. Intriguingly, NO donors stimulate $\mathrm{LH}$ and FSH release in a cGMP-independent manner $(254,259)$ implying that these effects reflect regulation of NO targets other than soluble guanylyl cyclases.

\section{CONCLUSION}

Type I mammalian GnRHRs of pituitary gonadotropes signal primarily via $\mathrm{G}_{\mathrm{q} / 11}$. Uniquely, they have no C-terminal tail and therefore do not elicit the C-tail dependent and heterotrimeric G-protein independent signaling seen with many other GPCRs. These features could ensure that the type I mammalian GnRHR of pituitary gonadotropes (e.g., the receptors that mediate central control of reproduction in humans) faithfully transduce the portal blood GnRH signal into PLC activation in the target cells, and this could arguably confer selective advantage by (i.e., facilitating the pre-ovulatory gonadotropin surge). Nevertheless, there is ample evidence that GnRHRs can activate other heterotrimeric G-proteins and that they do so in a cell context-dependent manner $(44,77,111,112,115,120,208,260-262)$. Notably, they apparently activate $G_{i}$ in some hormone-dependent cancer cell models and activate $G_{q / 11}, G_{s}$, and $G_{i}$ in GT1-7 neurons. Early work in primary cultures of pituitary cells revealed that $\mathrm{GnRH}$ increases cAMP production $(112,113)$ but this would not necessarily reflect $G_{s}$ activation and could even involve regulated cAMP production in cells other than gonadotropes. Subsequent work revealed little or no effect of GnRH on cAMP production in the gonadotrope-derived $\alpha$ T3-1 cell line $(120,208,216)$ as opposed to the stimulatory effects seen in the more mature L $\beta$ T2 gonadotrope cell line (77, 111). Such studies do not really address the fundamental question 
of physiological role. Thus, although it is well established that PLC-mediated effects on cytoplasmic $\mathrm{Ca}^{2+}$ and PKC influence exocytotic secretion of gonadotropins and transcriptional effects of GnRH, the relevance of GnRH effects on cAMP (and cGMP) production are much less clear. In this review we have highlighted two areas that may prove important in resolving this issue. The first is that paracrine or autocrine mechanisms exist for regulation of cyclic nucleotide production. Notably, PACAP has pronounced effects on cAMP production in gonadotropes and gonadotropederived cell lines, and the possibility exists that the modest stimulatory effects of $\mathrm{GnRH}$ pale into insignificance in gonadotropes exposed to PACAP. The second is that GnRH is secreted in pulses and very little is known about signaling of pulsatile GnRH via anything other than $\mathrm{G}_{\mathrm{q} / 11}$. Here, a key feature is that maximal effects of $\mathrm{GnRH}$ are often elicited at sub-maximal $\mathrm{GnRH}$ pulse frequency and mathematical modeling has revealed that such non-monotonic frequency-response curves could reflect cooperative activity of two (or more) convergent signaling pathways. This was explored for the $\mathrm{Ca}^{2+} /$ calmodulin/calcineurin/NFAT and Raf/MEK/ERK pathways but the same logic could equally apply to either (or both) of these pathways acting together with the $\mathrm{G}_{\mathrm{s}} / \mathrm{AC} / \mathrm{cAMP} / \mathrm{PKA}$ pathway. In this regard it is of interest that GnRHR activation actually reduces PACAP-stimulated cAMP production and CNP-stimulated cGMP production in $\alpha \mathrm{T} 3-1$ cells $(208,236)$ raising the question of whether GnRH pulses are stimulatory or inhibitory for these pathways in vivo. Clearly, a great deal is yet to be learned about cyclic nucleotide signaling in gonadotropes and how the signaling network integrates inputs via PLC, AC and GC.

\section{ACKNOWLEDGMENTS}

This work was funded Project Grants from MRC (93447) and the BBSRC (J014699).

\section{REFERENCES}

1. Cheng CK, Leung PC. Molecular biology of gonadotropin-releasing hormone (GnRH)-I, GnRH-Ii, and their receptors in humans. Endocr Rev (2005) 26:283-306. doi:10.1210/er.2003-0039

2. Ciccone NA, Kaiser UB. The biology of gonadotroph regulation. Curr Opin Endocrinol Diabetes Obes (2009) 16:321-7. doi:10.1097/MED. 0b013e $32832 \mathrm{~d} 88 \mathrm{fb}$

3. Millar RP, Lu ZL, Pawson AJ, Flanagan CA, Morgan K, Maudsley SR. Gonadotropin-releasing hormone receptors. Endocr Rev (2004) 25:235-75. doi:10.1210/er.2003-0002

4. Sealfon SC, Weinstein H, Millar RP. Molecular mechanisms of ligand interaction with the gonadotropin-releasing hormone receptor. Endocr Rev (1997) 18:180-205. doi:10.1210/er.18.2.180

5. Stojilkovic SS, Catt KJ. Novel aspects of GnRH-induced intracellular signaling and secretion in pituitary gonadotrophs. J Neuroendocrinol (1995) 7:739-57. doi:10.1111/j.1365-2826.1995.tb00711.x

6. Wang L, Chadwick W, Park SS, Zhou Y, Silver N, Martin B, et al. Gonadotropinreleasing hormone receptor system: modulatory role in aging and neurodegeneration. CNS Neurol Disord Drug Targets (2010) 9:651-60. doi:10.2174/ 187152710793361559

7. Cattanach BM, Iddon CA, Charlton HM, Chiappa SA, Fink G. Gonadotrophinreleasing hormone deficiency in a mutant mouse with hypogonadism. Nature (1977) 269:338-40. doi:10.1038/269338a0

8. Mason AJ, Hayflick JS, Zoeller RT, Young WS III, Phillips HS, Nikolics K, et al. A deletion truncating the gonadotropin-releasing hormone gene is responsible for hypogonadism in the hpg mouse. Science (1986) 234:1366-71. doi:10.1126/science.3024317

9. de Roux N, Young J, Misrahi M, Genet R, Chanson P, Schaison G, et al. A family with hypogonadotropic hypogonadism and mutations in the gonadotropinreleasing hormone receptor. N Engl J Med (1997) 337:1597-602. doi:10.1056/ NEJM199711273372205

10. Fernald RD, White RB. Gonadotropin-releasing hormone genes: phylogeny, structure, and functions. Front Neuroendocrinol (1999) 20:224-40. doi:10. 1006/frne.1999.0181

11. Schneider JS, Rissman EF. Gonadotropin-releasing hormone II: a multipurpose neuropeptide. Integr Comp Biol (2008) 48:588-95. doi:10.1093/icb/ icn018

12. White SA, Kasten TL, Bond CT, Adelman JP, Fernald RD. Three gonadotropinreleasing hormone genes in one organism suggest novel roles for an ancient peptide. Proc Natl Acad Sci U S A (1995) 92:8363-7. doi:10.1073/pnas.92.18. 8363

13. Yamamoto N, Oka Y, Amano M, Aida K, Hasegawa Y, Kawashima S. Multiple gonadotropin-releasing hormone $(\mathrm{GnRH})$-immunoreactive systems in the brain of the dwarf gourami, Colisa lalia: immunohistochemistry and radioimmunoassay. J Comp Neurol (1995) 355:354-68. doi:10.1002/cne. 903550303

14. Gothilf Y, Munoz-Cueto JA, Sagrillo CA, Selmanoff M, Chen TT, Kah O, et al. Three forms of gonadotropin-releasing hormone in a perciform fish (Sparus aurata): complementary deoxyribonucleic acid characterization and brain localization. Biol Reprod (1996) 55:636-45. doi:10.1095/biolreprod55.3.636

15. Parhar IS, Soga T, Sakuma Y. Quantitative in situ hybridization of three gonadotropin-releasing hormone-encoding mRNAs in castrated and progesterone-treated male tilapia. Gen Comp Endocrinol (1998) 112:406-14. doi:10.1006/gcen.1998.7143

16. Okubo K, Amano M, Yoshiura Y, Suetake H, Aida K. A novel form of gonadotropin-releasing hormone in the medaka, Oryzias latipes. Biochem Biophys Res Commun (2000) 276:298-303. doi:10.1006/bbrc.2000.3476

17. Amano M, Oka Y, Yamanome T, Okuzawa K, Yamamori K. Three GnRH systems in the brain and pituitary of a pleuronectiform fish, the barfin flounder Verasper moseri. Cell Tissue Res (2002) 309:323-9. doi:10.1007/s00441-002-0594-z

18. Vickers ED, Laberge F, Adams BA, Hara TJ, Sherwood NM. Cloning and localization of three forms of gonadotropin-releasing hormone, including the novel whitefish form, in a salmonid, Coregonus clupeaformis. Biol Reprod (2004) 70:1136-46. doi:10.1095/biolreprod.103.023846

19. Kuo MW, Lou SW, Postlethwait J, Chung BC. Chromosomal organization, evolutionary relationship, and expression of zebrafish GnRH family members. J Biomed Sci (2005) 12:629-39. doi:10.1007/s11373-005-7457-z

20. Mohamed JS, Thomas P, Khan IA. Isolation, cloning, and expression of three prepro-GnRH mRNAs in Atlantic croaker brain and pituitary. J Comp Neurol (2005) 488:384-95. doi:10.1002/cne.20596

21. Pandolfi M, Munoz Cueto JA, Lo Nostro FL, Downs JL, Paz DA, Maggese MC, et al. GnRH systems of Cichlasoma dimerus (Perciformes, Cichlidae) revisited: a localization study with antibodies and riboprobes to GnRH-associated peptides. Cell Tissue Res (2005) 321:219-32. doi:10.1007/s00441-004-1055-7

22. Soga T, Ogawa S, Millar RP, Sakuma Y, Parhar IS. Localization of the three GnRH types and GnRH receptors in the brain of a cichlid fish: insights into their neuroendocrine and neuromodulator functions. J Comp Neurol (2005) 487:28-41. doi:10.1002/cne.20519

23. Mohamed JS, Khan IA. Molecular cloning and differential expression of three GnRH mRNAs in discrete brain areas and lymphocytes in red drum. J Endocrinol (2006) 188:407-16. doi:10.1677/joe.1.06423

24. Morgan K, Millar RP. Evolution of GnRH ligand precursors and GnRH receptors in protochordate and vertebrate species. Gen Comp Endocrinol (2004) 139:191-7. doi:10.1016/j.ygcen.2004.09.015

25. Conn PM, Crowley WF Jr. Gonadotropin-releasing hormone and its analogs. Annu Rev Med (1994) 45:391-405. doi:10.1146/annurev.med.45.1.391

26. Belchetz P, Dufy B, Knobil E. Identification of inhibitory and stimulatory control of prolactin secretion in the rhesus monkey. Neuroendocrinology (1978) 27:32-8. doi:10.1159/000122798

27. Tsaneva-Atanasova K, Mina P, Caunt CJ, Armstrong SP, McArdle CA. Decoding GnRH neurohormone pulse frequency by convergent signalling modules. J R Soc Interface (2012) 9:170-82. doi:10.1098/rsif.2011.0215 
28. Schally AV. LH-RH analogues: I. Their impact on reproductive medicine. Gynecol Endocrinol (1999) 13:401-9. doi:10.3109/09513599909167587

29. Stojilkovic SS, Reinhart J, Catt KJ. Gonadotropin-releasing hormone receptors: structure and signal transduction pathways. Endocr Rev (1994) 15:462-99. doi:10.1210/er.15.4.462

30. Ruf F, Fink MY, Sealfon SC. Structure of the GnRH receptor-stimulated signaling network: insights from genomics. Front Neuroendocrinol (2003) 24:181-99. doi:10.1016/S0091-3022(03)00027-X

31. Jeong KH, Kaiser UB. Gonadotropin-releasing hormone regulation of gonadotropin biosynthesis and secretion. In: Knobil E, Neill JD, editors. The Physiology of Reproduction. 3rd ed. San Diego, CA: Elsevier (2006).

32. Cheung LW, Wong AS. Gonadotropin-releasing hormone: GnRH receptor signaling in extrapituitary tissues. FEBS J (2008) 275:5479-95. doi:10.1111/j. 1742-4658.2008.06677.x

33. Morgan K, Sellar R, Pawson AJ, Lu ZL, Millar RP. Bovine and ovine gonadotropin-releasing hormone $(\mathrm{GnRH})$-II ligand precursors and type II $\mathrm{GnRH}$ receptor genes are functionally inactivated. Endocrinology (2006) 147:5041-51. doi:10.1210/en.2006-0222

34. Eidne KA, Flanagan CA, Harris NS, Millar RP. Gonadotropin-releasing hormone $(\mathrm{GnRH})$-binding sites in human breast cancer cell lines and inhibitory effects of GnRH antagonists. J Clin Endocrinol Metab (1987) 64:425-32. doi:10.1210/jcem-64-3-425

35. Limonta P, Montagnani Marelli M, Moretti RM. LHRH analogues as anticancer agents: pituitary and extrapituitary sites of action. Expert Opin Investig Drugs (2001) 10:709-20. doi:10.1517/13543784.10.4.709

36. Finch AR, Green L, Hislop JN, Kelly E, McArdle CA. Signaling and antiproliferative effects of type I and II gonadotropin-releasing hormone receptors in breast cancer cells. J Clin Endocrinol Metab (2004) 89:1823-32. doi:10.1210/jc.2003-030787

37. Morgan K, Stewart AJ, Miller N, Mullen P, Muir M, Dodds M, et al. Gonadotropin-releasing hormone receptor levels and cell context affect tumor cell responses to agonist in vitro and in vivo. Cancer Res (2008) 68:6331-40. doi:10.1158/0008-5472.CAN-08-0197

38. Montagnani Marelli M, Moretti RM, Mai S, Januszkiewicz-Caulier J, Motta M, Limonta P. Type I gonadotropin-releasing hormone receptor mediates the antiproliferative effects of GnRH-II on prostate cancer cells. J Clin Endocrinol Metab (2009) 94:1761-7. doi:10.1210/jc.2008-1741

39. Fost C, Duwe F, Hellriegel M, Schweyer S, Emons G, Grundker C. Targeted chemotherapy for triple-negative breast cancers via LHRH receptor. Oncol Rep (2011) 25:1481-7. doi:10.3892/or.2011.1188

40. Limonta P, Montagnani Marelli M, Mai S, Motta M, Martini L, Moretti RM. GnRH receptors in cancer: from cell biology to novel targeted therapeutic strategies. Endocr Rev (2012) 33(5):784-811. doi:10.1210/er.2012-1014

41. Kraus S, Naor Z, Seger R. Intracellular signaling pathways mediated by the gonadotropin-releasing hormone $(\mathrm{GnRH})$ receptor. Arch Med Res (2001) 32:499-509. doi:10.1016/S0188-4409(01)00331-9

42. Pawson AJ, McNeilly AS. The pituitary effects of GnRH. Anim Reprod Sci (2005) 88:75-94. doi:10.1016/j.anireprosci.2005.05.010

43. Conn PM, Huckle WR, Andrews WV, McArdle CA. The molecular mechanism of action of gonadotropin releasing hormone $(\mathrm{GnRH})$ in the pituitary. Recent Prog Horm Res (1987) 43:29-68.

44. McArdle CA. Gonadotropin-releasing hormone receptor signaling: biased and unbiased. Mini Rev Med Chem (2012) 12:841-50. doi:10.2174/ 138955712800959080

45. Horn F, Bilezikjian LM, Perrin MH, Bosma MM, Windle JJ, Huber KS, et al. Intracellular responses to gonadotropin-releasing hormone in a clonal cell line of the gonadotrope lineage. Mol Endocrinol (1991) 5:347-55. doi:10.1210/ mend-5-3-347

46. McArdle CA, Huckle WR, Conn PM. Phorbol esters reduce gonadotrope responsiveness to protein kinase $\mathrm{C}$ activators but not to $\mathrm{Ca} 2+-$ mobilizing secretagogues. Does protein kinase $\mathrm{C}$ mediate gonadotropin-releasing hormone action? J Biol Chem (1987) 262:5028-35.

47. McArdle CA, Franklin J, Green L, Hislop JN. Signalling, cycling and desensitisation of gonadotrophin-releasing hormone receptors. J Endocrinol (2002) 173:1-11. doi:10.1677/joe.0.1730001

48. Rispoli LA, Nett TM. Pituitary gonadotropin-releasing hormone (GnRH) receptor: structure, distribution and regulation of expression. Anim Reprod Sci (2005) 88:57-74. doi:10.1016/j.anireprosci.2005.05.004
49. Bockaert J, Marin P, Dumuis A, Fagni L. The "magic tail" of G protein-coupled receptors: an anchorage for functional protein networks. FEBS Lett (2003) 546:65-72. doi:10.1016/S0014-5793(03)00453-8

50. Pierce KL, Lefkowitz RJ. Classical and new roles of beta-arrestins in the regulation of G-protein-coupled receptors. Nat Rev Neurosci (2001) 2:727-33. doi:10.1038/35094577

51. Heding A, Vrecl M, Bogerd J, McGregor A, Sellar R, Taylor PL, et al. Gonadotropin-releasing hormone receptors with intracellular carboxylterminal tails undergo acute desensitization of total inositol phosphate production and exhibit accelerated internalization kinetics. J Biol Chem (1998) 273:11472-7. doi:10.1074/jbc.273.19.11472

52. Blomenrohr M, Bogerd J, Leurs R, Goos H. Differences in structure-function relations between nonmammalian and mammalian $\mathrm{GnRH}$ receptors: what we have learnt from the African catfish GnRH receptor. Prog Brain Res (2002) 141:87-93. doi:10.1016/S0079-6123(02)41086-2

53. Davidson JS, Wakefield IK, Millar RP. Absence of rapid desensitization of the mouse gonadotropin-releasing hormone receptor. Biochem J (1994) 300(Pt 2):299-302.

54. Finch AR, Caunt CJ, Armstrong SP, McArdle CA. Agonist-induced internalization and downregulation of gonadotropin-releasing hormone receptors. Am J Physiol Cell Physiol (2009) 297:C591-600. doi:10.1152/ajpcell.00166.2009

55. Hislop JN, Madziva MT, Everest HM, Harding T, Uney JB, Willars GB, et al. Desensitization and internalization of human and Xenopus gonadotropinreleasing hormone receptors expressed in alphaT4 pituitary cells using recombinant adenovirus. Endocrinology (2000) 141:4564-75. doi:10.1210/en.141.12. 4564

56. Hislop JN, Everest HM, Flynn A, Harding T, Uney JB, Troskie BE, et al. Differential internalization of mammalian and non-mammalian gonadotropinreleasing hormone receptors. Uncoupling of dynamin-dependent internalization from mitogen-activated protein kinase signaling. J Biol Chem (2001) 276:39685-94. doi:10.1074/jbc.M104542200

57. Chen ZP, Kratzmeier M, Levy A, McArdle CA, Poch A, Day A, et al. Evidence for a role of pituitary ATP receptors in the regulation of pituitary function. Proc Natl Acad Sci U S A (1995) 92:5219-23. doi:10.1073/pnas.92.11.5219

58. McArdle CA, Davidson JS, Willars GB. The tail of the gonadotrophin-releasing hormone receptor: desensitization at, and distal to, $\mathrm{G}$ protein-coupled receptors. Mol Cell Endocrinol (1999) 151:129-36. doi:10.1016/S0303-7207(99) 00024-6

59. Vrecl M, Anderson L, Hanyaloglu A, McGregor AM, Groarke AD, Milligan G, et al. Agonist-induced endocytosis and recycling of the gonadotropin-releasing hormone receptor: effect of beta-arrestin on internalization kinetics. Mol Endocrinol (1998) 12:1818-29. doi:10.1210/me.12.12.1818

60. Pawson AJ, Katz A, Sun YM, Lopes J, Illing N, Millar RP, et al. Contrasting internalization kinetics of human and chicken gonadotropin-releasing hormone receptors mediated by C-terminal tail. J Endocrinol (1998) 156:R9-12. doi:10.1677/joe.0.156R009

61. Pawson AJ, Faccenda E, Maudsley S, Lu ZL, Naor Z, Millar RP. Mammalian type I gonadotropin-releasing hormone receptors undergo slow, constitutive, agonist-independent internalization. Endocrinology (2008) 149:1415-22. doi:10.1210/en.2007-1159

62. Castro-Fernandez C, Conn PM. Regulation of the gonadotropin-releasing hormone receptor (GnRHR) by RGS proteins: role of the GnRHR carboxyl terminus. Mol Cell Endocrinol (2002) 191:149-56. doi:10.1016/S03037207(02)00082-5

63. Hanyaloglu AC, Vrecl M, Kroeger KM, Miles LE, Qian H, Thomas WG, et al. Casein kinase II sites in the intracellular C-terminal domain of the thyrotropinreleasing hormone receptor and chimeric gonadotropin-releasing hormone receptors contribute to beta-arrestin-dependent internalization. J Biol Chem (2001) 276:18066-74. doi:10.1074/jbc.M009275200

64. Heding A, Vrecl M, Hanyaloglu AC, Sellar R, Taylor PL, Eidne KA. The rat gonadotropin-releasing hormone receptor internalizes via a betaarrestin-independent, but dynamin-dependent, pathway: addition of a carboxyl-terminal tail confers beta-arrestin dependency. Endocrinology (2000) 141:299-306. doi:10.1210/en.141.1.299

65. Hislop JN, Caunt CJ, Sedgley KR, Kelly E, Mundell S, Green LD, et al. Internalization of gonadotropin-releasing hormone receptors (GnRHRs): does arrestin binding to the C-terminal tail target GnRHRs for dynamin-dependent internalization? J Mol Endocrinol (2005) 35:177-89. doi:10.1677/jme.1.01809 
66. Acharjee S, Maiti K, Soh JM, Im WB, Seong JY, Kwon HB. Differential desensitization and internalization of three different bullfrog gonadotropin-releasing hormone receptors. Mol Cells (2002) 14:101-7.

67. Ronacher K, Matsiliza N, Nkwanyana N, Pawson AJ, Adam T, Flanagan CA, et al. Serine residues 338 and 339 in the carboxyl-terminal tail of the type II gonadotropin-releasing hormone receptor are critical for beta-arrestinindependent internalization. Endocrinology (2004) 145:4480-8. doi:10.1210/ en.2004-0075

68. Caunt CJ, Finch AR, Sedgley KR, McArdle CA. Seven-transmembrane receptor signalling and ERK compartmentalization. Trends Endocrinol Metab (2006) 17:276-83. doi:10.1016/j.tem.2006.07.008

69. Luttrell LM, Lefkowitz RJ. The role of beta-arrestins in the termination and transduction of G-protein-coupled receptor signals. J Cell Sci (2002) 115:455-65.

70. Kendall RT, Luttrell LM. Diversity in arrestin function. Cell Mol Life Sci (2009) 66:2953-73. doi:10.1007/s00018-009-0088-1

71. Luttrell LM, Roudabush FL, Choy EW, Miller WE, Field ME, Pierce KL, et al. Activation and targeting of extracellular signal-regulated kinases by betaarrestin scaffolds. Proc Natl Acad Sci U S A (2001) 98:2449-54. doi:10.1073/ pnas.041604898

72. Shenoy SK, Lefkowitz RJ. Multifaceted roles of beta-arrestins in the regulation of seven-membrane-spanning receptor trafficking and signalling. Biochem J (2003) 375:503-15. doi:10.1042/BJ20031076

73. Caunt CJ, Finch AR, Sedgley KR, McArdle CA. GnRH receptor signalling to ERK: kinetics and compartmentalization. Trends Endocrinol Metab (2006) 17:308-13. doi:10.1016/j.tem.2006.07.008

74. Caunt CJ, Finch AR, Sedgley KR, Oakley L, Luttrell LM, McArdle CA. Arrestin-mediated ERK activation by gonadotropin-releasing hormone receptors: receptor-specific activation mechanisms and compartmentalization. J Biol Chem (2006) 281:2701-10. doi:10.1074/jbc.M507242200

75. Hawes BE, Barnes S, Conn PM. Cholera toxin and pertussis toxin provoke differential effects on luteinizing hormone release, inositol phosphate production, and gonadotropin-releasing hormone $(\mathrm{GnRH})$ receptor binding in the gonadotrope: evidence for multiple guanyl nucleotide binding proteins in GnRH action. Endocrinology (1993) 132:2124-30.

76. Stanislaus D, Ponder S, Ji TH, Conn PM. Gonadotropin-releasing hormone receptor couples to multiple $\mathrm{G}$ proteins in rat gonadotrophs and in GGH3 cells: evidence from palmitoylation and overexpression of $\mathrm{G}$ proteins. Biol Reprod (1998) 59:579-86. doi:10.1095/biolreprod59.3.579

77. Liu F, Usui I, Evans LG, Austin DA, Mellon PL, Olefsky JM, et al. Involvement of both $\mathrm{G}(\mathrm{q} / 11)$ and $\mathrm{G}(\mathrm{s})$ proteins in gonadotropin-releasing hormone receptormediated signaling in L beta T2 cells. J Biol Chem (2002) 277:32099-108. doi:10.1074/jbc.M203639200

78. Grundker C, Volker P, Emons G. Antiproliferative signaling of luteinizing hormone-releasing hormone in human endometrial and ovarian cancer cells through $\mathrm{G}$ protein alpha(I)-mediated activation of phosphotyrosine phosphatase. Endocrinology (2001) 142:2369-80. doi:10.1210/en.142.6. 2369

79. Naor Z. Signaling by G-protein-coupled receptor (GPCR): studies on the GnRH receptor. Front Neuroendocrinol (2009) 30:10-29. doi:10.1016/j.yfrne. 2008.07.001

80. Stojilkovic SS, Iida T, Merelli F, Torsello A, Krsmanovic LZ, Catt KJ. Interactions between calcium and protein kinase $\mathrm{C}$ in the control of signaling and secretion in pituitary gonadotrophs. J Biol Chem (1991) 266:10377-84.

81. Iida T, Stojilkovic SS, Izumi S, Catt KJ. Spontaneous and agonist-induced calcium oscillations in pituitary gonadotrophs. Mol Endocrinol (1991) 5:949-58. doi:10.1210/mend-5-7-949

82. Leong DA, Thorner MO. A potential code of luteinizing hormone-releasing hormone-induced calcium ion responses in the regulation of luteinizing hormone secretion among individual gonadotropes. J Biol Chem (1991) 266:9016-22.

83. Hansen JR, McArdle CA, Conn PM. Relative roles of calcium derived from intra- and extracellular sources in dynamic luteinizing hormone release from perifused pituitary cells. Mol Endocrinol (1987) 1:808-15. doi:10.1210/mend1-11-808

84. Stojilkovic SS, Tomic M, Kukuljan M, Catt KJ. Control of calcium spiking frequency in pituitary gonadotrophs by a single-pool cytoplasmic oscillator. $\mathrm{Mol}$ Pharmacol (1994) 45:1013-21.
85. Mulvaney JM, Roberson MS. Divergent signaling pathways requiring discrete calcium signals mediate concurrent activation of two mitogen-activated protein kinases by gonadotropin-releasing hormone. J Biol Chem (2000) 275:14182-9. doi:10.1074/jbc.275.19.14182

86. Roberson MS, Misra-Press A, Laurance ME, Stork PJ, Maurer RA. A role for mitogen-activated protein kinase in mediating activation of the glycoprotein hormone alpha-subunit promoter by gonadotropin-releasing hormone. Mol Cell Biol (1995) 15:3531-9.

87. Harris D, Chuderland D, Bonfil D, Kraus S, Seger R, Naor Z. Extracellular signal-regulated kinase and c-Src, but not Jun N-terminal kinase, are involved in basal and gonadotropin-releasing hormone-stimulated activity of the glycoprotein hormone alpha-subunit promoter. Endocrinology (2003) 144:612-22. doi:10.1210/en.2002-220690

88. Weck J, Fallest PC, Pitt LK, Shupnik MA. Differential gonadotropin-releasing hormone stimulation of rat luteinizing hormone subunit gene transcription by calcium influx and mitogen-activated protein kinase-signaling pathways. $\mathrm{Mol}$ Endocrinol (1998) 12:451-7. doi:10.1210/me.12.3.451

89. Fowkes RC, King P, Burrin JM. Regulation of human glycoprotein hormone alpha-subunit gene transcription in LbetaT2 gonadotropes by protein kinase $\mathrm{C}$ and extracellular signal-regulated kinase 1/2. Biol Reprod (2002) 67:725-34. doi:10.1095/biolreprod67.3.725

90. Harris D, Bonfil D, Chuderland D, Kraus S, Seger R, Naor Z. Activation of MAPK cascades by GnRH: ERK and Jun N-terminal kinase are involved in basal and GnRH-stimulated activity of the glycoprotein hormone LHbeta-subunit promoter. Endocrinology (2002) 143:1018-25. doi:10.1210/en.143.3.1018

91. Liu F, Austin DA, Mellon PL, Olefsky JM, Webster NJ. GnRH activates ERK1/2 leading to the induction of c-fos and LHbeta protein expression in LbetaT2 cells. Mol Endocrinol (2002) 16:419-34. doi:10.1210/me.16.3.419

92. Call GB, Wolfe MW. Gonadotropin-releasing hormone activates the equine luteinizing hormone beta promoter through a protein kinase $\mathrm{C} / \mathrm{mitogen}$ activated protein kinase pathway. Biol Reprod (1999) 61:715-23. doi:10.1095/ biolreprod61.3.715

93. Kanasaki H, Bedecarrats GY, Kam KY, Xu S, Kaiser UB. Gonadotropinreleasing hormone pulse frequency-dependent activation of extracellular signal-regulated kinase pathways in perifused LbetaT2 cells. Endocrinology (2005) 146:5503-13. doi:10.1210/en.2004-1317

94. Bonfil D, Chuderland D, Kraus S, Shahbazian D, Friedberg I, Seger R, et al. Extracellular signal-regulated kinase, Jun N-terminal kinase, p38, and c-Src are involved in gonadotropin-releasing hormone-stimulated activity of the glycoprotein hormone follicle-stimulating hormone beta-subunit promoter. Endocrinology (2004) 145:2228-44. doi:10.1210/en.2003-1418

95. Vasilyev VV, Pernasetti F, Rosenberg SB, Barsoum MJ, Austin DA, Webster NJ, et al. Transcriptional activation of the ovine follicle-stimulating hormone-beta gene by gonadotropin-releasing hormone involves multiple signal transduction pathways. Endocrinology (2002) 143:1651-9. doi:10.1210/en.143.5.1651

96. Wang Y, Fortin J, Lamba P, Bonomi M, Persani L, Roberson MS, et al. Activator protein- 1 and smad proteins synergistically regulate human follicle-stimulating hormone beta-promoter activity. Endocrinology (2008) 149:5577-91. doi:10. 1210/en.2008-0220

97. Kowase T, Walsh HE, Darling DS, Shupnik MA. Estrogen enhances gonadotropin-releasing hormone-stimulated transcription of the luteinizing hormone subunit promoters via altered expression of stimulatory and suppressive transcription factors. Endocrinology (2007) 148:6083-91. doi:10.1210/en. 2007-0407

98. Ferris HA, Walsh HE, Stevens J, Fallest PC, Shupnik MA. Luteinizing hormone beta promoter stimulation by adenylyl cyclase and cooperation with gonadotropin-releasing hormone 1 in transgenic mice and LBetaT2 cells. Biol Reprod (2007) 77:1073-80. doi:10.1095/biolreprod.107.064139

99. Bliss SP, Miller A, Navratil AM, Xie J, McDonough SP, Fisher PJ, et al. ERK signaling in the pituitary is required for female but not male fertility. Mol Endocrinol (2009) 23:1092-101. doi:10.1210/me.2009-0030

100. Burger LL, Haisenleder DJ, Dalkin AC, Marshall JC. Regulation of gonadotropin subunit gene transcription. J Mol Endocrinol (2004) 33:559-84. doi:10.1677/jme.1.01600

101. Burger LL, Haisenleder DJ, Aylor KW, Marshall JC. Regulation of Lhb and Egr 1 gene expression by GNRH pulses in rat pituitaries is both c-Jun N-terminal kinase (JNK) - and extracellular signal-regulated kinase (ERK)-dependent. Biol Reprod (2009) 81:1206-15. doi:10.1095/biolreprod.109.079426 
102. Xie J, Bliss SP, Nett TM, Ebersole BJ, Sealfon SC, Roberson MS. Transcript profiling of immediate early genes reveals a unique role for activating transcription factor 3 in mediating activation of the glycoprotein hormone alphasubunit promoter by gonadotropin-releasing hormone. Mol Endocrinol (2005) 19:2624-38. doi:10.1210/me.2005-0056

103. Roberson MS, Zhang T, Li HL, Mulvaney JM. Activation of the p38 mitogen-activated protein kinase pathway by gonadotropin-releasing hormone. Endocrinology (1999) 140:1310-8. doi:10.1210/en.140.3.1310

104. Haisenleder DJ, Burger LL, Walsh HE, Stevens J, Aylor KW, Shupnik MA, et al. Pulsatile gonadotropin-releasing hormone stimulation of gonadotropin subunit transcription in rat pituitaries: evidence for the involvement of Jun Nterminal kinase but not p38. Endocrinology (2008) 149:139-45. doi:10.1210/ en.2007-1113

105. Yokoi T, Ohmichi M, Tasaka K, Kimura A, Kanda Y, Hayakawa J, et al. Activation of the luteinizing hormone beta promoter by gonadotropin-releasing hormone requires c-Jun NH2-terminal protein kinase. J Biol Chem (2000) 275:21639-47. doi:10.1074/jbc.M910252199

106. Kraus S, Benard O, Naor Z, Seger R. c-Src is activated by the epidermal growth factor receptor in a pathway that mediates JNK and ERK activation by gonadotropin-releasing hormone in COS7 cells. J Biol Chem (2003) 278:32618-30. doi:10.1074/jbc.M303886200

107. Levi NL, Hanoch T, Benard O, Rozenblat M, Harris D, Reiss N, et al. Stimulation of Jun N-terminal kinase (JNK) by gonadotropin-releasing hormone in pituitary alpha T3-1 cell line is mediated by protein kinase C, c-Src, and CDC42. Mol Endocrinol (1998) 12:815-24. doi:10.1210/me.12.6.815

108. Coss D, Hand CM, Yaphockun KK, Ely HA, Mellon PL. p38 Mitogen-activated protein kinase is critical for synergistic induction of the $\mathrm{FSH}$ (beta) gene by gonadotropin-releasing hormone and activin through augmentation of c-Fos induction and Smad phosphorylation. Mol Endocrinol (2007) 21:3071-86. doi:10.1210/me.2007-0247

109. Lim S, Pnueli L, Tan JH, Naor Z, Rajagopal G, Melamed P. Negative feedback governs gonadotrope frequency-decoding of gonadotropin releasing hormone pulse-frequency. PLoS One (2009) 4:e7244. doi:10.1371/journal. pone. 0007244

110. Mayer SI, Willars GB, Nishida E, Thiel G. Elk-1, Creb, and MKP-1 regulate Egr1 expression in gonadotropin-releasing hormone stimulated gonadotrophs. J Cell Biochem (2008) 105:1267-78. doi:10.1002/jcb.21927

111. Lariviere S, Garrel G, Simon V, Soh JW, Laverriere JN, Counis R, et al. Gonadotropin-releasing hormone couples to 3',5'-cyclic adenosine-5'monophosphate pathway through novel protein kinase Cdelta and -epsilon in LbetaT2 gonadotrope cells. Endocrinology (2007) 148:1099-107. doi:10.1210/ en.2006-1473

112. Borgeat P, Chavancy G, Dupont A, Labrie F, Arimura A, Schally AV. Stimulation of adenosine $3^{\prime}: 5^{\prime}$-cyclic monophosphate accumulation in anterior pituitary gland in vitro by synthetic luteinizing hormone-releasing hormone. Proc Natl Acad Sci U S A (1972) 69:2677-81. doi:10.1073/pnas.69.9.2677

113. Naor Z, Koch Y, Chobsieng P, Zor U. Pituitary cyclic AMP production and mechanism of luteinizing hormone release. FEBS Lett (1975) 58:318-21. doi:10.1016/0014-5793(75)80288-2

114. Liu F, Austin DA, Webster NJ. Gonadotropin-releasing hormone-desensitized LbetaT2 gonadotrope cells are refractory to acute protein kinase C, cyclic Amp, and calcium-dependent signaling. Endocrinology (2003) 144:4354-65. doi:10.1210/en.2003-0204

115. Arora KK, Krsmanovic LZ, Mores N, O’Farrell H, Catt KJ. Mediation of cyclic AMP signaling by the first intracellular loop of the gonadotropin-releasing hormone receptor. J Biol Chem (1998) 273:25581-6. doi:10.1074/jbc.273.40. 25581

116. Lin X, Janovick JA, Conn PM. Mutations at the consensus phosphorylation sites in the third intracellular loop of the rat gonadotropin-releasing hormone receptor: effects on receptor ligand binding and signal transduction. Biol Reprod (1998) 59:1470-6. doi:10.1095/biolreprod59.6.1470

117. Oh DY, Song JA, Moon JS, Moon MJ, Kim JI, Kim K, et al. Membraneproximal region of the carboxyl terminus of the gonadotropin-releasing hormone receptor (GnRHR) confers differential signal transduction between mammalian and nonmammalian GnRHRs. Mol Endocrinol (2005) 19:722-31. doi:10.1210/me.2004-0220

118. Conn PM, Morrell DV, Dufau ML, Catt KJ. Gonadotropin-releasing hormone action in cultured pituicytes: independence of luteinizing hormone release and adenosine 3',5'-monophosphate production. Endocrinology (1979) 104:448-53. doi:10.1210/endo-104-2-448

119. Theoleyre M, Berault A, Garnier J, Jutisz M. Binding of gonadotropinreleasing hormone ( $\mathrm{LH}-\mathrm{RH})$ to the pituitary plasma membranes and the problem of adenylate cyclase stimulation. Mol Cell Endocrinol (1976) 5:365-77. doi:10.1016/0303-7207(76)90019-8

120. Grosse R, Schmid A, Schoneberg T, Herrlich A, Muhn P, Schultz G, et al. Gonadotropin-releasing hormone receptor initiates multiple signaling pathways by exclusively coupling to $\mathrm{G}(\mathrm{q} / 11)$ proteins. J Biol Chem (2000) 275:9193-200. doi:10.1074/jbc.275.13.9193

121. Avet C, Garrel G, Denoyelle C, Laverriere JN, Counis R, Cohen-Tannoudji J, et al. SET protein interacts with intracellular domains of the gonadotropinreleasing hormone receptor and differentially regulates receptor signaling to cAMP and calcium in gonadotrope cells. J Biol Chem (2013) 288:2641-54. doi:10.1074/jbc.M112.388876

122. Andrade J, Quinn J, Becker RZ, Shupnik MA. AMP-activated protein kinase is a key intermediary in GnRH-stimulated LHbeta gene transcription. Mol Endocrinol (2013) 27:828-39. doi:10.1210/me.2012-1323

123. Duan WR, Shin JL, Jameson JL. Estradiol suppresses phosphorylation of cyclic adenosine 3',5'-monophosphate response element binding protein (CREB) in the pituitary: evidence for indirect action via gonadotropin-releasing hormone. Mol Endocrinol (1999) 13:1338-52. doi:10.1210/me.13.8.1338

124. Maurer RA, Kim KE, Schoderbek WE, Roberson MS, Glenn DJ. Regulation of glycoprotein hormone alpha-subunit gene expression. Recent Prog Horm Res (1999) 54:455-84; discussion 485.

125. Delegeane AM, Ferland LH, Mellon PL. Tissue-specific enhancer of the human glycoprotein hormone alpha-subunit gene: dependence on cyclic AMPinducible elements. Mol Cell Biol (1987) 7:3994-4002.

126. Haisenleder DJ, Yasin M, Marshall JC. Enhanced effectiveness of pulsatile 3',5'-cyclic adenosine monophosphate in stimulating prolactin and alphasubunit gene expression. Endocrinology (1992) 131:3027-33. doi:10.1210/en. 131.6.3027

127. Brown P, McNeilly AS. Transcriptional regulation of pituitary gonadotrophin subunit genes. Rev Reprod (1999) 4:117-24. doi:10.1530/ror.0.0040117

128. Counis R, Laverriere JN, Garrel G, Bleux C, Cohen-Tannoudji J, Lerrant Y, et al. Gonadotropin-releasing hormone and the control of gonadotrope function. Reprod Nutr Dev (2005) 45:243-54. doi:10.1051/rnd:2005017

129. Berridge MJ. Module 2: cell signalling pathways. Cell Signal Biol (2012) 2.12.130. doi:10.1042/csb0001002

130. Haisenleder DJ, Burger LL, Aylor KW, Dalkin AC, Walsh HE, Shupnik MA et al. Testosterone stimulates follicle-stimulating hormone beta transcription via activation of extracellular signal-regulated kinase: evidence in rat pituitary cells. Biol Reprod (2005) 72:523-9. doi:10.1095/biolreprod.104.035196

131. Fox EM, Andrade J, Shupnik MA. Novel actions of estrogen to promote proliferation: integration of cytoplasmic and nuclear pathways. Steroids (2009) 74:622-7. doi:10.1016/j.steroids.2008.10.014

132. Chu Z, Andrade J, Shupnik MA, Moenter SM. Differential regulation of gonadotropin-releasing hormone neuron activity and membrane properties by acutely applied estradiol: dependence on dose and estrogen receptor subtype. J Neurosci (2009) 29:5616-27. doi:10.1523/JNEUROSCI.0352-09.2009

133. Wang X, Muratani M, Tansey WP, Ptashne M. Proteolytic instability and the action of nonclassical transcriptional activators. Curr Biol (2010) 20:868-71. doi:10.1016/j.cub.2010.03.029

134. Melamed P. Hormonal signaling to follicle stimulating hormone beta-subunit gene expression. Mol Cell Endocrinol (2010) 314:204-12. doi:10.1016/j.mce. 2009.05.012

135. Naor Z, Catt KJ. Independent actions of gonadotropin releasing hormone upon cyclic GMP production and luteinizing hormone release. J Biol Chem (1980) 255:342-4.

136. Lozach A, Garrel G, Lerrant Y, Berault A, Counis R. GnRH-dependent upregulation of nitric oxide synthase I level in pituitary gonadotrophs mediates cGMP elevation during rat proestrus. Mol Cell Endocrinol (1998) 143:43-51. doi:10.1016/S0303-7207(98)00135-X

137. Garrel G, Lerrant Y, Siriostis C, Berault A, Magre S, Bouchaud C, et al. Evidence that gonadotropin-releasing hormone stimulates gene expression and levels of active nitric oxide synthase type I in pituitary gonadotrophs, a process altered by desensitization and, indirectly, by gonadal steroids. Endocrinology (1998) 139:2163-70. doi:10.1210/en.139.4.2163 
138. Davidson L, Pawson AJ, Lopez DE, Maturana R, Freestone SH, Barran P, et al. Gonadotropin-releasing hormone-induced activation of diacylglycerol kinase-zeta and its association with active c-src. J Biol Chem (2004) 279:11906-16. doi:10.1074/jbc.M310784200

139. Davidson L, Pawson AJ, Millar RP, Maudsley S. Cytoskeletal reorganization dependence of signaling by the gonadotropin-releasing hormone receptor. J Biol Chem (2004) 279:1980-93. doi:10.1074/jbc.M309827200

140. Gardner S, Maudsley S, Millar RP, Pawson AJ. Nuclear stabilization of betacatenin and inactivation of glycogen synthase kinase-3beta by gonadotropinreleasing hormone: targeting Wnt signaling in the pituitary gonadotrope. $\mathrm{Mol}$ Endocrinol (2007) 21:3028-38. doi:10.1210/me.2007-0268

141. Dierschke DJ, Bhattacharya AN, Atkinson LE, Knobil E. Circhoral oscillations of plasma LH levels in the ovariectomized rhesus monkey. Endocrinology (1970) 87:850-3. doi:10.1210/endo-87-5-850

142. Clarke IJ, Cummins JT. The temporal relationship between gonadotropin releasing hormone $(\mathrm{GnRH})$ and luteinizing hormone $(\mathrm{LH})$ secretion in ovariectomized ewes. Endocrinology (1982) 111:1737-9. doi:10.1210/endo111-5- 1737

143. Belchetz PE, Plant TM, Nakai Y, Keogh EJ, Knobil E. Hypophysial responses to continuous and intermittent delivery of hypopthalamic gonadotropinreleasing hormone. Science (1978) 202:631-3. doi:10.1126/science.100883

144. Daulny A, Geng F, Muratani M, Geisinger JM, Salghetti SE, Tansey WP. Modulation of RNA polymerase II subunit composition by ubiquitylation. Proc Natl Acad Sci U S A (2008) 105:19649-54. doi:10.1073/pnas.0809372105

145. Ferris HA, Shupnik MA. Mechanisms for pulsatile regulation of the gonadotropin subunit genes by GNRH1. Biol Reprod (2006) 74:993-8. doi: 10.1095/biolreprod.105.049049

146. Kaiser UB, Jakubowiak A, Steinberger A, Chin WW. Regulation of rat pituitary gonadotropin-releasing hormone receptor mRNA levels in vivo and in vitro. Endocrinology (1993) 133:931-4. doi:10.1210/en.133.2.931

147. Yasin M, Dalkin AC, Haisenleder DJ, Kerrigan JR, Marshall JC. Gonadotropinreleasing hormone $(\mathrm{GnRH})$ pulse pattern regulates $\mathrm{GnRH}$ receptor gene expression: augmentation by estradiol. Endocrinology (1995) 136:1559-64. doi:10.1210/en.136.4.1559

148. Dalkin AC, Haisenleder DJ, Ortolano GA, Ellis TR, Marshall JC. The frequency of gonadotropin-releasing-hormone stimulation differentially regulates gonadotropin subunit messenger ribonucleic acid expression. Endocrinology (1989) 125:917-24. doi:10.1210/endo-125-2-917

149. Haisenleder DJ, Dalkin AC, Ortolano GA, Marshall JC, Shupnik MA. A pulsatile gonadotropin-releasing hormone stimulus is required to increase transcription of the gonadotropin subunit genes: evidence for differential regulation of transcription by pulse frequency in vivo. Endocrinology (1991) 128:509-17. doi:10.1210/endo-128-1-509

150. Shupnik MA. Effects of gonadotropin-releasing hormone on rat gonadotropin gene transcription in vitro: requirement for pulsatile administration for luteinizing hormone-beta gene stimulation. Mol Endocrinol (1990) 4:1444-50. doi:10.1210/mend-4-10-1444

151. Weiss J, Jameson JL, Burrin JM, Crowley WF Jr. Divergent responses of gonadotropin subunit messenger RNAs to continuous versus pulsatile gonadotropin-releasing hormone in vitro. Mol Endocrinol (1990) 4:557-64. doi:10.1210/mend-4-4-557

152. Haisenleder DJ, Ortolano GA, Dalkin AC, Ellis TR, Paul SJ, Marshall JC. Differential regulation of gonadotropin subunit gene expression by gonadotropinreleasing hormone pulse amplitude in female rats. Endocrinology (1990) 127:2869-75. doi:10.1210/endo-127-6-2869

153. Papavasiliou SS, Zmeili S, Khoury S, Landefeld TD, Chin WW, Marshall JC. Gonadotropin-releasing hormone differentially regulates expression of the genes for luteinizing hormone alpha and beta subunits in male rats. Proc Natl Acad Sci U S A (1986) 83:4026-9. doi:10.1073/pnas.83.11.4026

154. Wildt L, Hausler A, Marshall G, Hutchison JS, Plant TM, Belchetz PE, et al. Frequency and amplitude of gonadotropin-releasing hormone stimulation and gonadotropin secretion in the rhesus monkey. Endocrinology (1981) 109:376-85. doi:10.1210/endo-109-2-376

155. Gross KM, Matsumoto AM, Bremner WJ. Differential control of luteinizing hormone and follicle-stimulating hormone secretion by luteinizing hormonereleasing hormone pulse frequency in man. J Clin Endocrinol Metab (1987) 64:675-80. doi:10.1210/jcem-64-4-675
156. Spratt DI, Finkelstein JS, Butler JP, Badger TM, Crowley WF Jr. Effects of increasing the frequency of low doses of gonadotropin-releasing hormone (GnRH) on gonadotropin secretion in GnRH-deficient men. J Clin Endocrinol Metab (1987) 64:1179-86. doi:10.1210/jcem-64-6-1179

157. Bedecarrats GY, Kaiser UB. Differential regulation of gonadotropin subunit gene promoter activity by pulsatile gonadotropin-releasing hormone $(\mathrm{GnRH})$ in perifused L beta T2 cells: role of GnRH receptor concentration. Endocrinology (2003) 144:1802-11. doi:10.1210/en.2002-221140

158. Bliss SP, Navratil AM, Xie J, Roberson MS. GnRH signaling, the gonadotrope and endocrine control of fertility. Front Neuroendocrinol (2010) 31:322-40. doi:10.1016/j.yfrne.2010.04.002

159. Armstrong SP, Caunt CJ, Fowkes RC, Tsaneva-Atanasova K, McArdle CA. Pulsatile and sustained gonadotropin-releasing hormone $(\mathrm{GnRH})$ receptor signaling: does the $\mathrm{Ca} 2+$ /NFAT signaling pathway decode $\mathrm{GnRH}$ pulse frequency? J Biol Chem (2009) 284:35746-57. doi:10.1074/jbc.M109.063917

160. Armstrong SP, Caunt CJ, McArdle CA. Gonadotropin-releasing hormone and protein kinase $\mathrm{C}$ signaling to ERK: spatiotemporal regulation of ERK by docking domains and dual-specificity phosphatases. Mol Endocrinol (2009) 23:510-9. doi:10.1210/me.2008-0333

161. Ciccone NA, Xu S, Lacza CT, Carroll RS, Kaiser UB. Frequency-dependent regulation of follicle-stimulating hormone beta by pulsatile gonadotropin-releasing hormone is mediated by functional antagonism of bZIP transcription factors. Mol Cell Biol (2010) 30:1028-40. doi:10.1128/MCB.00848-09

162. Lawson MA, Tsutsumi R, Zhang H, Talukdar I, Butler BK, Santos SJ, et al. Pulse sensitivity of the luteinizing hormone beta promoter is determined by a negative feedback loop Involving early growth response- 1 and Ngfi-A binding protein 1 and 2. Mol Endocrinol (2007) 21:1175-91. doi:10.1210/me.2006-0392

163. Krakauer DC, Page KM, Sealfon S. Module dynamics of the GnRH signal transduction network. J Theor Biol (2002) 218:457-70. doi:10.1016/S0022-5193(02) 93092-4

164. Finch AR, Caunt CJ, Armstrong SP, McArdle CA. Plasma membrane expression of gonadotropin-releasing hormone receptors: regulation by peptide and nonpeptide antagonists. Mol Endocrinol (2010) 24:423-35. doi:10.1210/me.20090343

165. Washington TM, Blum JJ, Reed MC, Conn PM. A mathematical model for LH release in response to continuous and pulsatile exposure of gonadotrophs to GnRH. Theor Biol Med Model (2004) 1:9. doi:10.1186/1742-4682-1-9

166. Karakoula A, Tovey SC, Brighton PJ, Willars GB. Lack of receptor-selective effects of either RGS2, RGS3 or RGS4 on muscarinic M3- and gonadotropinreleasing hormone receptor-mediated signalling through G alpha $\mathrm{q} / 11$. Eur J Pharmacol (2008) 587:16-24. doi:10.1016/j.ejphar.2008.03.047

167. Wurmbach E, Yuen T, Ebersole BJ, Sealfon SC. Gonadotropin-releasing hormone receptor-coupled gene network organization. J Biol Chem (2001) 276:47195-201. doi:10.1074/jbc.M108716200

168. Willars GB, Royall JE, Nahorski SR, EL-Gehani F, Everest H, McArdle CA. Rapid down-regulation of the type I inositol 1,4,5-trisphosphate receptor and desensitization of gonadotropin-releasing hormone-mediated $\mathrm{Ca} 2+$ responses in alpha T3-1 gonadotropes. J Biol Chem (2001) 276:3123-9. doi:10.1074/jbc. M008916200

169. Wojcikiewicz RJ, Xu Q, Webster JM, Alzayady K, Gao C. Ubiquitination and proteasomal degradation of endogenous and exogenous inositol 1,4,5trisphosphate receptors in alpha T3-1 anterior pituitary cells. J Biol Chem (2003) 278:940-7. doi:10.1074/jbc.M206607200

170. Muratani M, Tansey WP. How the ubiquitin-proteasome system controls transcription. Nat Rev Mol Cell Biol (2003) 4:192-201. doi:10.1038/nrm1049

171. Walsh HE, Shupnik MA. Proteasome regulation of dynamic transcription factor occupancy on the GnRH-stimulated luteinizing hormone beta-subunit promoter. Mol Endocrinol (2009) 23:237-50. doi:10.1210/me.2008-0098

172. Thompson IR, Ciccone NA, Xu S, Zaytseva S, Carroll RS, Kaiser UB. GnRH pulse frequency-dependent stimulation of FSHbeta transcription is mediated via activation of PKA and CREB. Mol Endocrinol (2013) 27:606-18. doi:10.1210/me.2012-1281

173. Mistry DS, Tsutsumi R, Fernandez M, Sharma S, Cardenas SA, Lawson MA, et al. Gonadotropin-releasing hormone pulse sensitivity of follicle-stimulating hormone-beta gene is mediated by differential expression of positive regulatory activator protein 1 factors and corepressors SKIL and TGIF1. Mol Endocrinol (2011) 25:1387-403. doi:10.1210/me.2011-0032 
174. Reddy GR, Xie C, Lindaman LL, Coss D. GnRH increases c-Fos half-life contributing to higher FSHbeta induction. Mol Endocrinol (2013) 27:253-65. doi:10.1210/me.2012-1168

175. Armstrong SP, Caunt CJ, Fowkes RC, Tsaneva-Atanasova K, McArdle CA. Pulsatile and sustained gonadotropin-releasing hormone $(\mathrm{GnRH})$ receptor signaling: does the ERK signaling pathway decode GnRH pulse frequency? J Biol Chem (2010) 285:24360-71. doi:10.1074/jbc.M110.115964

176. Macian F. NFAT proteins: key regulators of T-cell development and function. Nat Rev Immunol (2005) 5:472-84. doi:10.1038/nri1632

177. Berridge MJ. Remodelling Ca2+ signalling systems and cardiac hypertrophy. Biochem Soc Trans (2006) 34:228-31. doi:10.1042/BST20060228

178. Cooling MT, Hunter P, Crampin EJ. Sensitivity of NFAT cycling to cytosolic calcium concentration: implications for hypertrophic signals in cardiac myocytes. Biophys J (2009) 96:2095-104. doi:10.1016/j.bpj.2008.11.064

179. Hanson PI, Meyer T, Stryer L, Schulman H. Dual role of calmodulin in autophosphorylation of multifunctional CaM kinase may underlie decoding of calcium signals. Neuron (1994) 12:943-56. doi:10.1016/0896-6273(94) 90306-9

180. Macián F, García-Rodríguez C, Rao A. Gene expression elicited by NFAT in the presence or absence of cooperative recruitment of Fos and Jun. EMBO J (2000) 19:4783-95. doi:10.1093/emboj/19.17.4783

181. Macián F, López-Rodríguez C, Rao A. Partners in transcription: NFAT and AP-1. Oncogene (2001) 20:2476-89. doi:10.1038/sj.onc. 1204386

182. Sanna B, Bueno OF, Dai Y-S, Wilkins BJ, Molkentin JD. Direct and indirect interactions between calcineurin-NFAT and MEK1-extracellular signal-regulated kinase 1/2 signaling pathways regulate cardiac gene expression and cellular growth. Mol Cell Biol (2005) 25:865-78. doi:10.1128/MCB.25.3.865-878.2005

183. Tomida T, Hirose K, Takizawa A, Shibasaki F, Iino M. NFAT functions as a working memory of a signals in decoding a oscillation. EMBO J (2003) 22:3825-32. doi:10.1093/emboj/cdg381

184. Ruf F, Hayot F, Park MJ, Ge Y, Lin G, Roysam B, et al. Noise propagation and scaling in regulation of gonadotrope biosynthesis. Biophys $J$ (2007) 93:4474-80. doi:10.1529/biophysj.107.115170

185. Ruf F, Park MJ, Hayot F, Lin G, Roysam B, Ge Y, et al. Mixed analog/digital gonadotrope biosynthetic response to gonadotropin-releasing hormone. J Biol Chem (2006) 281:30967-78. doi:10.1074/jbc.M606486200

186. Li Y, Rinzel J, Keizer J, Stojilkovic SS. Calcium oscillations in pituitary gonadotrophs: comparison of experiment and theory. Proc Natl Acad Sci US A (1994) 91:58-62. doi:10.1073/pnas.91.1.58

187. Nelson SB, Eraly SA, Mellon PL. The GnRH promoter: target of transcription factors, hormones, and signaling pathways. Mol Cell Endocrinol (1998) 140:151-5. doi:10.1016/S0303-7207(98)00043-4

188. Tsutsumi R, Mistry D, Webster NJ. Signaling responses to pulsatile gonadotropin-releasing hormone in LbetaT2 gonadotrope cells. J Biol Chem (2010) 285:20262-72. doi:10.1074/jbc.M110.132662

189. McArdle CA, Bunting R, Mason WT. Dynamic video imaging of cystolic $\mathrm{Ca}(2+)$ in the alphaT3-1, gonadotrope-derived cell line. Mol Cell Neurosci (1992) 3:124-32. doi:10.1016/1044-7431(92)90016-U

190. Evans JJ, Forrest-Owen W, McArdle CA. Oxytocin receptor-mediated activation of phosphoinositidase $\mathrm{C}$ and elevation of cytosolic calcium in the gonadotrope-derived alphaT3-1 cell line. Endocrinology (1997) 138:2049-55. doi:10.1210/en.138.5.2049

191. Rao K, Paik WY, Zheng L, Jobin RM, Tomic M, Jiang H, et al. Wortmanninsensitive and -insensitive steps in calcium-controlled exocytosis in pituitary gonadotrophs: evidence that myosin light chain kinase mediates calciumdependent and wortmannin-sensitive gonadotropin secretion. Endocrinology (1997) 138:1440-9. doi:10.1210/en.138.4.1440

192. McArdle CA, Willars GB, Fowkes RC, Nahorski SR, Davidson JS, Forrest-Owen W. Desensitization of gonadotropin-releasing hormone action in alphaT3-1 cells due to uncoupling of inositol 1,4,5-trisphosphate generation and $\mathrm{Ca} 2+$ mobilization. J Biol Chem (1996) 271:23711-7. doi:10.1074/jbc.271.39.23711

193. Choi SG, Jia J, Pfeffer RL, Sealfon SC. G proteins and autocrine signaling differentially regulate gonadotropin subunit expression in pituitary gonadotrope. J Biol Chem (2012) 287:21550-60. doi:10.1074/jbc.M112.348607

194. Denef C. Paracrinicity: the story of 30 years of cellular pituitary crosstalk. J Neuroendocrinol (2008) 20:1-70. doi:10.1111/j.1365-2826.2007.01616.x

195. Miyata A, Arimura A, Dahl RR, Minamino N, Uehara A, Jiang L, et al. Isolation of a novel 38 residue-hypothalamic polypeptide which stimulates adenylate cyclase in pituitary cells. Biochem Biophys Res Commun (1989) 164:567-74. doi:10.1016/0006-291X(89)91757-9

196. Miyata A, Jiang L, Dahl RD, Kitada C, Kubo K, Fujino M, et al. Isolation of a neuropeptide corresponding to the N-terminal 27 residues of the pituitary adenylate cyclase activating polypeptide with 38 residues (PACAP38). Biochem Biophys Res Commun (1990) 170:643-8. doi:10.1016/0006-291X(90) 92140-U

197. Winters SJ, Moore JP Jr. PACAP, an autocrine/paracrine regulator of gonadotrophs. Biol Reprod (2011) 84:844-50. doi:10.1095/biolreprod.110. 087593

198. Sherwood NM, Krueckl SL, McRory JE. The origin and function of the pituitary adenylate cyclase-activating polypeptide (PACAP)/glucagon superfamily. Endocr Rev (2000) 21:619-70. doi:10.1210/er.21.6.619

199. Alexander SP, Mathie A, Peters JA. Guide to receptors and channels (GRAC), 5th edition. Br J Pharmacol (2011) 164(Suppl 1):S1-324. doi:10.1111/j.14765381.2011.01649_1.x

200. Rawlings SR, Hezareh M. Pituitary adenylate cyclase-activating polypeptide (PACAP) and PACAP/vasoactive intestinal polypeptide receptors: actions on the anterior pituitary gland. Endocr Rev (1996) 17:4-29. doi:10.1210/edrv-17$1-4$

201. Dickson L, Aramori I, Sharkey J, Finlayson K. VIP and PACAP receptor pharmacology: a comparison of intracellular signaling pathways. Ann N Y Acad Sci (2006) 1070:239-42. doi:10.1196/annals.1317.021

202. Dickson L, Finlayson K. VPAC and PAC receptors: from ligands to function. Pharmacol Ther (2009) 121:294-316. doi:10.1016/j.pharmthera.2008.11.006

203. Spengler D, Waeber C, Pantaloni C, Holsboer F, Bockaert J, Seeburg PH, et al. Differential signal transduction by five splice variants of the PACAP receptor. Nature (1993) 365:170-5. doi:10.1038/365170a0

204. Muratani M, Kung C, Shokat KM, Tansey WP. The F box protein Dsg1/Mdm30 is a transcriptional coactivator that stimulates Gal4 turnover and cotranscriptional mRNA processing. Cell (2005) 120:887-99. doi:10.1016/j.cell.2004.12. 025

205. Grundker C, Schlotawa L, Viereck V, Emons G. Protein kinase C-independent stimulation of activator protein-1 and c-Jun N-terminal kinase activity in human endometrial cancer cells by the LHRH agonist triptorelin. Eur J Endocrinol (2001) 145:651-8. doi:10.1530/eje.0.1450651

206. Rawlings SR, Berry DJ, Leong DA. Evidence for localized calcium mobilization and influx in single rat gonadotropes. J Biol Chem (1991) 266:22755-60.

207. Canny BJ, Rawlings SR, Leong DA. Pituitary adenylate cyclase-activating polypeptide specifically increases cytosolic calcium ion concentration in rat gonadotropes and somatotropes. Endocrinology (1992) 130:211-5. doi:10. 1210/en.130.1.211

208. McArdle CA, Poch A, Schomerus E, Kratzmeier M. Pituitary adenylate cyclaseactivating polypeptide effects in pituitary cells: modulation by gonadotropinreleasing hormone in alpha T3-1 cells. Endocrinology (1994) 134:2599-605. doi:10.1210/en.134.6.2599

209. Schomerus E, Poch A, Bunting R, Mason WT, McArdle CA. Effects of pituitary adenylate cyclase-activating polypeptide in the pituitary: activation of two signal transduction pathways in the gonadotrope-derived alpha T3-1 cell line. Endocrinology (1994) 134:315-23. doi:10.1210/en.134.1.315

210. Winters SJ, Moore JP. Paracrine control of gonadotrophs. Semin Reprod Med (2007) 25:379-87. doi:10.1055/s-2007-984744

211. Winters SJ, Ghooray D, Fujii Y, Moore JP Jr, Nevitt JR, Kakar SS. Transcriptional regulation of follistatin expression by $\mathrm{GnRH}$ in mouse gonadotroph cell lines: evidence for a role for cAMP signaling. Mol Cell Endocrinol (2007) 271:45-54. doi:10.1016/j.mce.2007.03.006

212. Culler MD, Paschall CS. Pituitary adenylate cyclase-activating polypeptide (PACAP) potentiates the gonadotropin-releasing activity of luteinizing hormone-releasing hormone. Endocrinology (1991) 129:2260-2. doi:10.1210/ endo-129-4-2260

213. McArdle CA. Pituitary adenylate cyclase-activating polypeptide: a key player in reproduction? Endocrinology (1994) 135:815-7. doi:10.1210/en.135.3.815

214. Tsujii T, Attardi B, Winters SJ. Regulation of alpha-subunit mRNA transcripts by pituitary adenylate cyclase-activating polypeptide (PACAP) in pituitary cell cultures and alpha T3-1 cells. Mol Cell Endocrinol (1995) 113:123-30. doi:10.1016/0303-7207(95)03613-C

215. Tsujii T, Winters SJ. Effects of pulsatile pituitary adenylate cyclase activating polypeptide (PACAP) on gonadotropin secretion and subunit mRNA levels 
in perifused rat pituitary cells. Life Sci (1995) 56:1103-11. doi:10.1016/00243205(95)00047-A

216. McArdle CA, Counis R. GnRH and PACAP action in gonadotropes: cross-talk between phosphoinositidase $\mathrm{C}$ and adenylyl cyclase mediated signaling pathways. Trends Endocrinol Metab (1996) 7:168-75. doi:10.1016/1043-2760(96) 00051-3

217. Counis R, Laverriere JN, Garrel-Lazayres G, COHEN-Tannoudji J, Lariviere S, Bleux C, et al. What is the role of PACAP in gonadotrope function? Peptides (2007) 28:1797-804. doi:10.1016/j.peptides.2007.05.011

218. Hipskind RA, Rao VN, Mueller CG, Reddy ES, Nordheim A. Ets-related protein Elk-1 is homologous to the c-fos regulatory factor p62TCF. Nature (1991) 354:531-4. doi:10.1038/354531a0

219. Tsujii T, Ishizaka K, Winters SJ. Effects of pituitary adenylate cyclase-activating polypeptide on gonadotropin secretion and subunit messenger ribonucleic acids in perifused rat pituitary cells. Endocrinology (1994) 135:826-33. doi:10. 1210/en.135.3.826

220. Kanasaki H, Purwana IN, Mijiddorj T, Oride A, Miyazaki K. Possible involvement of PACAP and PACAP type 1 receptor in GnRH-induced FSH betasubunit gene expression. Regul Pept (2011) 167:227-32. doi:10.1016/j.regpep. 2011.02.010

221. Kanasaki H, Mutiara S, Oride A, Purwana IN, Miyazaki K. Pulse frequencydependent gonadotropin gene expression by adenylate cyclase-activating polypeptide 1 in perifused mouse pituitary gonadotroph LbetaT2 cells. Biol Reprod (2009) 81:465-72. doi:10.1095/biolreprod.108.074765

222. Purwana IN, Kanasaki H, Oride A, Mijiddorj T, Shintani N, Hashimoto $\mathrm{H}$, et al. GnRH-induced PACAP and PAC1 receptor expression in pituitary gonadotrophs: a possible role in the regulation of gonadotropin subunit gene expression. Peptides (2010) 31:1748-55. doi:10.1016/j.peptides.2010.05.012

223. Purwana IN, Kanasaki H, Oride A, Mijiddorj T, Miyazaki K. Expression of the pituitary adenylate cyclase-activating polypeptide (PACAP) type 1 receptor (PAC1R) potentiates the effects of $\mathrm{GnRH}$ on gonadotropin subunit gene expression. Biochem Biophys Res Commun (2011) 410:295-300. doi:10.1016/j.bbrc.2011.05.135

224. Zawaski K, Gruebele A, Kaplan D, Reddy S, Mortensen A, Novak RF. Evidence for enhanced expression of c-fos, $\mathrm{c}$-jun, and the $\mathrm{Ca}(2+)$-activated neutral protease in rat liver following carbon tetrachloride administration. Biochem Biophys Res Commun (1993) 197:585-90. doi:10.1006/bbrc.1993.2519

225. Winters SJ, Dalkin AC, Tsujii T. Evidence that pituitary adenylate cyclase activating polypeptide suppresses follicle-stimulating hormone-beta messenger ribonucleic acid levels by stimulating follistatin gene transcription. Endocrinology (1997) 138:4324-9. doi:10.1210/en.138.10.4324

226. Fujii Y, Okada Y, Moore JP Jr, Dalkin AC, Winters SJ. Evidence that PACAP and GnRH down-regulate follicle-stimulating hormone-beta mRNA levels by stimulating follistatin gene expression: effects on folliculostellate cells, gonadotrophs and LbetaT2 gonadotroph cells. Mol Cell Endocrinol (2002) 192:55-64. doi:10.1016/S0303-7207(02)00109-0

227. Koul D, Shen R, Shishodia S, Takada Y, Bhat KP, Reddy SA, et al. PTEN down regulates AP-1 and targets c-fos in human glioma cells via PI3-kinase/Akt pathway. Mol Cell Biochem (2007) 300:77-87. doi:10.1007/s11010-006-9371-8

228. Fowkes RC, McArdle CA. C-type natriuretic peptide: an important neuroendocrine regulator? Trends Endocrinol Metab (2000) 11:333-8. doi:10.1016/ S1043-2760(00)00288-5

229. Potter LR, Abbey-Hosch S, Dickey DM. Natriuretic peptides, their receptors, and cyclic guanosine monophosphate-dependent signaling functions. Endocr Rev (2006) 27:47-72. doi:10.1210/er.2005-0014

230. Baxter GF. The natriuretic peptides. Basic Res Cardiol (2004) 99:71-5. doi:10. 1007/s00395-004-0457-8

231. Chusho H, Tamura N, Ogawa Y, Yasoda A, Suda M, Miyazawa T, et al. Dwarfism and early death in mice lacking C-type natriuretic peptide. Proc Natl Acad Sci U S A (2001) 98:4016-21. doi:10.1073/pnas.071389098

232. McArdle CA, Olcese J, Schmidt C, Poch A, Kratzmeier M, Middendorff R. Ctype natriuretic peptide $(\mathrm{CNP})$ in the pituitary: is $\mathrm{CNP}$ an autocrine regulator of gonadotropes? Endocrinology (1994) 135:2794-801. doi:10.1210/en.135.6. 2794

233. Thompson IR, Chand AN, Jonas KC, Burrin JM, Steinhelper ME, WheelerJones CP, et al. Molecular characterisation and functional interrogation of a local natriuretic peptide system in rodent pituitaries, alphaT3-1 and LbetaT2 gonadotroph cells. J Endocrinol (2009) 203:215-29. doi:10.1677/JOE-09-0189
234. Tamura N, Doolittle LK, Hammer RE, Shelton JM, Richardson JA, Garbers DL. Critical roles of the guanylyl cyclase B receptor in endochondral ossification and development of female reproductive organs. Proc Natl Acad Sci U S A (2004) 101:17300-5. doi:10.1073/pnas.0407894101

235. Olcese J, Middendorff R, Munker M, Schmidt C, McArdle CA. Natriuretic peptides stimulate cyclic GMP production in an immortalized LHRH neuronal cell line. J Neuroendocrinol (1994) 6:127-30. doi:10.1111/j.1365-2826.1994. tb00562.x

236. McArdle CA, Poch A, Kappler K. Cyclic guanosine monophosphate production in the pituitary: stimulation by C-type natriuretic peptide and inhibition by gonadotropin-releasing hormone in alpha T3-1 cells. Endocrinology (1993) 132:2065-72. doi:10.1210/en.132.5.2065

237. Khurana ML, Pandey KN. Receptor-mediated stimulatory effect of atrial natriuretic factor, brain natriuretic peptide, and C-type natriuretic peptide on testosterone production in purified mouse Leydig cells: activation of cholesterol side-chain cleavage enzyme. Endocrinology (1993) 133:2141-9. doi:10.1210/en.133.5.2141

238. Huang H, Acuff CG, Steinhelper ME. Isolation, mapping, and regulated expression of the gene encoding mouse C-type natriuretic peptide. Am J Physiol (1996) 271:H1565-75.

239. Middendorff R, Muller D, Paust HJ, Davidoff MS, Mukhopadhyay AK. Natriuretic peptides in the human testis: evidence for a potential role of C-type natriuretic peptide in Leydig cells. J Clin Endocrinol Metab (1996) 81:4324-8. doi:10.1210/jc.81.12.4324

240. Acuff CG, Huang H, Steinhelper ME. Estradiol induces C-type natriuretic peptide gene expression in mouse uterus. Am J Physiol (1997) 273:H2672-7.

241. Jankowski M, Reis AM, Mukaddam-Daher S, Dam TV, Farookhi R, Gutkowska J. C-type natriuretic peptide and the guanylyl cyclase receptors in the rat ovary are modulated by the estrous cycle. Biol Reprod (1997) 56:59-66. doi:10.1095/biolreprod56.1.59

242. Gutkowska J, Jankowski M, Sairam MR, Fujio N, Reis AM, Mukaddam-Daher $S$, et al. Hormonal regulation of natriuretic peptide system during induced ovarian follicular development in the rat. Biol Reprod (1999) 61:162-70. doi:10.1095/biolreprod61.1.162

243. Stepan H, Leitner E, Walter K, Bader M, Schultheiss H, Faber R, et al. Gestational regulation of the gene expression of C-type natriuretic peptide in mouse reproductive and embryonic tissue. Regul Pept (2001) 102:9-13. doi:10.1016/S0167-0115(01)00299-3

244. Walther T, Stepan H. C-type natriuretic peptide in reproduction, pregnancy and fetal development. J Endocrinol (2004) 180:17-22. doi:10.1677/joe.0. 1800017

245. Fowkes RC, Forrest-Owen W, Williams B, McArdle CA. C-type natriuretic peptide (CNP) effects on intracellular calcium $[\mathrm{Ca} 2+]$ i in mouse gonadotropederived alphaT3-1 cell line. Regul Pept (1999) 84:43-9. doi:10.1016/S01670115(99)00066-X

246. Ceccatelli S, Hulting AL, Zhang X, Gustafsson L, Villar M, Hokfelt T. Nitric oxide synthase in the rat anterior pituitary gland and the role of nitric oxide in regulation of luteinizing hormone secretion. Proc Natl Acad Sci U S A (1993) 90:11292-6. doi:10.1073/pnas.90.23.11292

247. Knowles RG, Moncada S. Nitric oxide synthases in mammals. Biochem J (1994) 298(Pt 2):249-58.

248. Murad F. The 1996 Albert Lasker medical research awards. Signal transduction using nitric oxide and cyclic guanosine monophosphate. JAMA (1996) 276:1189-92. doi:10.1001/jama.276.14.1189

249. Lloyd RV, Jin L, Qian X, Zhang S, Scheithauer BW. Nitric oxide synthase in the human pituitary gland. Am J Pathol (1995) 146:86-94.

250. Garrel G, Lozach A, Bachir LK, Laverriere JN, Counis R. Pituitary adenylate cyclase-activating polypeptide stimulates nitric-oxide synthase type I expression and potentiates the cGMP response to gonadotropin-releasing hormone of rat pituitary gonadotrophs. J Biol Chem (2002) 277:46391-401. doi:10.1074/jbc.M203763200

251. Bachir LK, Laverriere JN, Counis R. Isolation and characterization of a rat nitric oxide synthase type I gene promoter that confers expression and regulation in pituitary gonadotrope cells. Endocrinology (2001) 142:4631-42. doi:10.1210/en.142.11.4631

252. Bachir LK, Garrel G, Lozach A, Laverriere JN, Counis R. The rat pituitary promoter of the neuronal nitric oxide synthase gene contains an Sp1-, LIM homeodomain-dependent enhancer and a distinct bipartite 
gonadotropin-releasing hormone-responsive region. Endocrinology (2003) 144:3995-4007. doi:10.1210/en.2002-0183

253. Wei X, Sasaki M, Huang H, Dawson VL, Dawson TM. The orphan nuclear receptor, steroidogenic factor 1 , regulates neuronal nitric oxide synthase gene expression in pituitary gonadotropes. Mol Endocrinol (2002) 16:2828-39. doi:10.1210/me.2001-0273

254. Ceccatelli S. Expression and plasticity of NO synthase in the neuroendocrine system. Brain Res Bull (1997) 44:533-8. doi:10.1016/S0361-9230(97)00239-6

255. Chatterjee S, Collins TJ, Yallampalli C. Inhibition of nitric oxide facilitates LH release from rat pituitaries. Life Sci (1997) 61:45-50. doi:10.1016/S00243205(97)00356-1

256. Barnes MJ, Lapanowski K, Rafols JA, Lawson DM, Dunbar JC. Chronic nitric oxide deficiency is associated with altered leutinizing hormone and folliclestimulating hormone release in ovariectomized rats. Exp Biol Med (Maywood) (2002) 227:817-22.

257. Barnes MJ, Lapanowski K, Rafols JA, Lawson DM, Dunbar JC. GnRH and gonadotropin release is decreased in chronic nitric oxide deficiency. Exp Biol Med (Maywood) (2001) 226:701-6.

258. Chiodera P, Volpi R, Manfredi G, Bortesi ML, Capretti L, Magotti MG, et al. Effect of oxytocin on nitric oxide activity controlling gonadotropin secretion in humans. Eur J Clin Invest (2003) 33:402-5. doi:10.1046/j.1365-2362.2003. 01122.x

259. Pinilla L, Gonzalez D, Tena-Sempere M, Aguilar E. Nitric oxide (NO) stimulates gonadotropin secretion in vitro through a calcium-dependent, cGMPindependent mechanism. Neuroendocrinology (1998) 68:180-6. doi:10.1159/ 000054364

260. Maudsley S, Davidson L, Pawson AJ, Chan R, Lopez DE, Maturana R, et al. Gonadotropin-releasing hormone $(\mathrm{GnRH})$ antagonists promote proapoptotic signaling in peripheral reproductive tumor cells by activating a Galphaicoupling state of the type I GnRH receptor. Cancer Res (2004) 64:7533-44. doi:10.1158/0008-5472.CAN-04-1360

261. Krsmanovic LZ, Mores N, Navarro CE, Tomic M, Catt KJ. Regulation of Ca2+sensitive adenylyl cyclase in gonadotropin-releasing hormone neurons. Mol Endocrinol (2001) 15:429-40. doi:10.1210/me.15.3.429

262. Krsmanovic LZ, Mores N, Navarro CE, Arora KK, Catt KJ. An agonist-induced switch in $\mathrm{G}$ protein coupling of the gonadotropin-releasing hormone receptor regulates pulsatile neuropeptide secretion. Proc Natl Acad Sci U S A (2003) 100:2969-74. doi:10.1073/pnas.0535708100

Conflict of Interest Statement: The authors declare that the research was conducted in the absence of any commercial or financial relationships that could be construed as a potential conflict of interest.

Received: 07 August 2013; accepted: 06 November 2013; published online: 20 November 2013.

Citation: Perrett RM and McArdle CA (2013) Molecular mechanisms of gonadotropinreleasing hormone signaling: integrating cyclic nucleotides into the network. Front. Endocrinol. 4:180. doi: 10.3389/fendo.2013.00180

This article was submitted to Pituitary Endocrinology, a section of the journal Frontiers in Endocrinology.

Copyright (c) 2013 Perrett and McArdle. This is an open-access article distributed under the terms of the Creative Commons Attribution License (CC BY). The use, distribution or reproduction in other forums is permitted, provided the original author (s) or licensor are credited and that the original publication in this journal is cited, in accordance with accepted academic practice. No use, distribution or reproduction is permitted which does not comply with these terms. 